\title{
Protection against Peroxynitrite-Mediated Nitration Reaction by Intramolecularly Coordinated
} Diorganoselenides

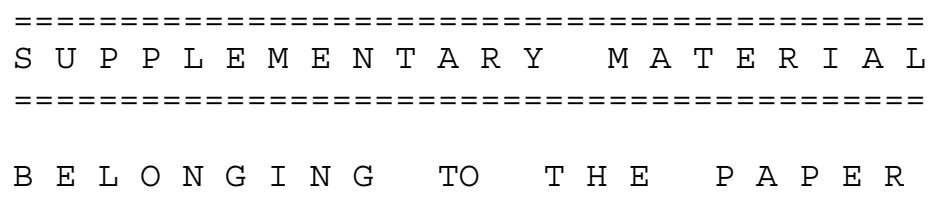

Organometallics

b y

Sangit Kumar, ${ }^{\dagger}$ Harkesh B. Singh, ${ }^{*},{ }^{\dagger}$ and Gotthelf Wolmershäuser ${ }^{\ddagger}$

Department of Chemistry, Indian Institute of Technology Bombay, Powai, Mumbai

400 076, India and Fachbereich Chemie, Universität Kaiserslautern, Postfach 3049,

Kaiserslautern 67653, Germany

E-mail: chhbsia@chem.iitb.ac.in 
Synthesis of $N$-Phenylferrocenecarboxamide (41): To a stirred solution of ferrocenecarboxylic acid $(2.30 \mathrm{~g}, 10 \mathrm{mmol})$ in $\mathrm{CH}_{2} \mathrm{Cl}_{2}(10 \mathrm{~mL})$ was added oxalyl chloride (1.32 mL, $15 \mathrm{mmol})$ via syringe at room temperature under nitrogen. Gas evolution was accompanied by the formation of a dark red colored homogeneous solution. After $30 \mathrm{~min}$, solvent was removed under vacuo. The resultant crude ferrocenoyl chloride was isolated as a red oil that crystallized on standing, was taken up in $\mathrm{CH}_{2} \mathrm{Cl}_{2}(20 \mathrm{~mL})$ and added via syringe to a solution of phenyl amine $(0.93 \mathrm{~g}, 10 \mathrm{mmol})$ and triethyl amine $(2.1 \mathrm{~mL}, 15$ mmol) under nitrogen at $0{ }^{\circ} \mathrm{C}$. The reactiom mixture was stirred overnight. The dark red colored reaction mixture was washed with $2 \times 50 \mathrm{~mL}$ of water and extracted with $2 \times 50$ $\mathrm{mL}$ of $\mathrm{CH}_{2} \mathrm{Cl}_{2}$ and dried over $\mathrm{Na}_{2} \mathrm{SO}_{4}$ and concentrate under vacuo. The crude product was purified by column chromatography using $\mathrm{SiO}_{2}$ (60-120 mess) and $\mathrm{CH}_{2} \mathrm{Cl}_{2} / \mathrm{CH}_{3} \mathrm{OH}$ (9.8:0.2) to give compound $\mathbf{4 1}$ as a yellow crystalline powder. Yield: $2.85 \mathrm{~g}$ (93.4\%), m.p. $198-202{ }^{\circ} \mathrm{C}$; Anal.Calcd. for $\mathrm{C}_{17} \mathrm{H}_{15}$ FeNO: C, 66.91; H, 4.95; N, 4.58. Found: C, 66.59, H, 4.92; N, 4.81. ${ }^{1} \mathrm{H}$ NMR $\left(\mathrm{CDCl}_{3}\right) \delta 4.26(\mathrm{~s}, 5 \mathrm{H}), 4.44(\mathrm{t}, 2 \mathrm{H}), 4.78(\mathrm{t}, 2 \mathrm{H}), 7.08-$ $7.16(\mathrm{~m}, 1 \mathrm{H}), 7.32-7.41(\mathrm{~m}, 2 \mathrm{H})$, 7.56-7.64 (m, 2H); IR (KBr): 3294, 3085, 2921, 1642, 1313, $696\left(\mathrm{~cm}^{-1}\right)$. All other data are consistent with the values reported in the literature. ${ }^{1}$ Synthesis of Bis[2-(N-phenyl ferrocenylcarboxamide)] diselenide (43): To a stirred solution of ferrocenecarboxamide $41(0.61 \mathrm{~g}, 2 \mathrm{mmol})$ in dry THF $(35 \mathrm{~mL})$ under $\mathrm{N}_{2}$ at 0 ${ }^{\circ} \mathrm{C}$ was added $n$-BuLi (2.3 mL, $4.2 \mathrm{mmol}, 1.6 \mathrm{M}$ solution in hexane) dropwise( ca 1 drop/10 sec). A dark red color, homogenous solution of dianion was formed after $40 \mathrm{~min}$. Elemental selenium $(0.16 \mathrm{~g}, 2 \mathrm{mmol})$ was added to the resulting reaction mixture under a brisk flow of $\mathrm{N}_{2}$ to exclude the air. The selenium powder consumed rapidly to give a homogenous solution of blackish red colored, lithiumselonolate (42). To the reaction 
mixture of 42 a solution of $\mathrm{CuBr}_{2}(0.44 \mathrm{~g}, 4.2 \mathrm{mmol})$ in THF $(10 \mathrm{~mL})$ was added drop wise at $-78{ }^{\circ} \mathrm{C}$. The reaction mixture was placed in a separating funnel and extract with $\mathrm{CH}_{2} \mathrm{Cl}_{2}(2 \times 25 \mathrm{~mL})$. Standard work up followed by column chromatography using $\mathrm{SiO}_{2}$ (60-120 mess), $\mathrm{CH}_{2} \mathrm{Cl}_{2} / \mathrm{CH}_{3} \mathrm{OH}$ (18:2) gave red color solid of 43. Recrystallization from $\mathrm{CH}_{2} \mathrm{Cl}_{2}$ and $\mathrm{CH}_{3} \mathrm{OH}$ afforded dark red colored crystal. Yield: $0.52 \mathrm{~g} \mathrm{(68 \% ),} \mathrm{mp} \mathrm{138-140}$ ${ }^{\circ} \mathrm{C}$; Anal. Calcd. for $\mathrm{C}_{34} \mathrm{H}_{28} \mathrm{Fe}_{2} \mathrm{~N}_{2} \mathrm{O}_{2} \mathrm{Se}_{2}$ : C, 53.32; H, 3.68; N, 3.65. Found: C, 53.16, H, 3.71; N, 3.48. ${ }^{1} \mathrm{H}$ NMR $\left(\mathrm{CDCl}_{3}\right) \delta 4.21(\mathrm{~s}, 10 \mathrm{H}), 4.34-4.56(\mathrm{~m}, 4 \mathrm{H}), 5.04-5.10(\mathrm{~m}, 2 \mathrm{H})$, 7.06-7.14 (m, 4H),7.26-7.36 (m, 4H), $7.48(\mathrm{~d}, 2 \mathrm{H}), 9.07(\mathrm{~d}, 2 \mathrm{H}) ;{ }^{13} \mathrm{C} \mathrm{NMR}\left(\mathrm{CDCl}_{3}\right): \delta$ $71.3,71.49,72.03,72.65,72.85,73.65,80.39,119.6,123.8,128.8,167.8 .{ }^{77}$ Se NMR $\left(\mathrm{CDCl}_{3}\right) \delta$ 484; IR (KBr): 3302, 3093, 2927, 2855, 1657, 1604, 1532, 1440, 1249, 762 $\left(\mathrm{cm}^{-1}\right) . \mathrm{Ms}(\mathrm{FAB}): \mathrm{m} / \mathrm{z}$ 768(M $\left.\mathrm{M}^{+}\right), 701,613,460,307,289,165,154,138,120,107$. 


\section{Protection by organoselenium compounds against peroxynitrite-mediated nitration}

reaction: 4-Hydroxyphenylacetate (4-HPA) reacts with peroxynitrite (PN) and produces 4-hydroxy-3-nitrophenylacetate $\left(\mathrm{NO}_{2}\right.$-HPA) as shown in the Scheme $\mathrm{S}-1{ }^{2}$

Scheme S-1. Nitration in 4-HPA and oxidation of diorganoselenides by PN

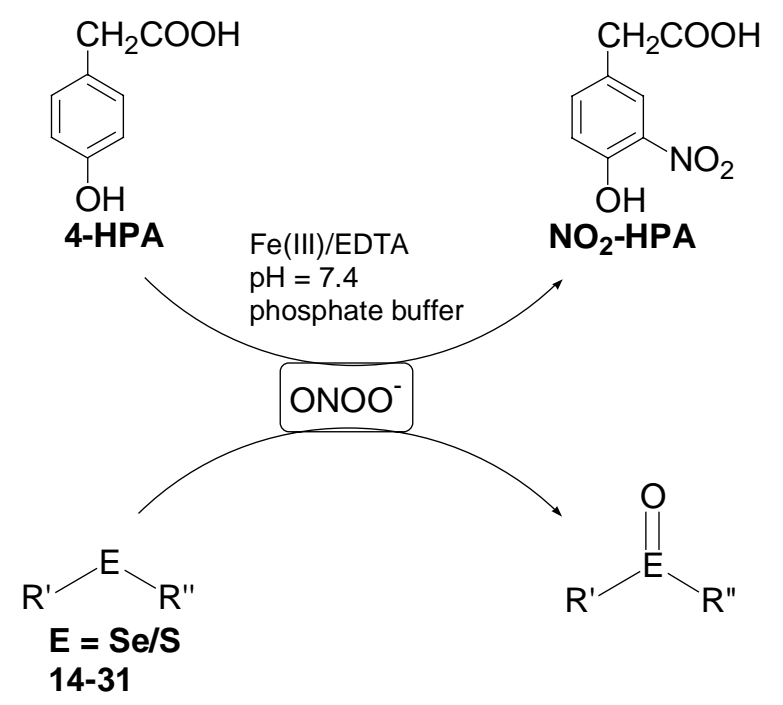

The formation of $\mathrm{NO}_{2}$-HPA is followed by UV-Visible spectrometer at $430 \mathrm{~nm}, \varepsilon=4,400$ $\mathrm{M}^{-1} \mathrm{~cm}^{-1}$. Low formation of $\mathrm{NO}_{2}$-HPA takes place in the presence of diorganoselenides (diorganoselenide react with PN and convert it to selenoxide and reduce the initial concentration of $\mathrm{PN})$. Thus concentration of $\mathrm{NO}_{2}-\mathrm{HPA}$ is a measure of the protective effect of diorganoselenides against $\mathrm{PN}$ in the above nitration reaction. The low formation of $\mathrm{NO}_{2}-\mathrm{HPA}$ indicates that the diorganoselenide is more effective to inhibit the nitration reaction and vice versa.

Experiments were conducted at room temperature in a $0.1 \mathrm{M}$ sodium phosphate buffer (pH 7.4) containing $\mathrm{Fe}(\mathrm{III}) / \mathrm{EDTA}(0.5 \mathrm{mM})$ [Fe(III)/ EDTA complex was prepared by mixing equimolar solution of Fe(III) chloride and sodium EDTA], 4-HPA (1 $\mathrm{mM})$ and various concentration of diorganoselenids in methanol. PN $(50 \mu \mathrm{M})$ was added 
to the above reaction mixture under constant stirring. Reaction mixtures were mixed for 30 min at room temperature and then $\mathrm{pH}$ was adjusted to $10-11$ with $1 \mathrm{M} \mathrm{NaOH}$ before absorbance measured at $430 \mathrm{~nm}$. The yield of the nitrated product $\mathrm{NO}_{2}-\mathrm{HPA}$ was calculated by using $\varepsilon=4,400 \mathrm{M}^{-1} \mathrm{~cm}^{-1}$. The result of the reaction of 4-HPA with PN and methanol alone was set equal to $100 \%$.

Table 1: Concentration of $\mathrm{NO}_{2}-\mathrm{HPA}$ at various concentration of Ebselen (2)

\begin{tabular}{|l|l|c|c|c|}
\hline Sr. No. & $\mathbf{2}[\mathrm{C}] \mu \mathrm{M}$ & $\mathrm{A}(430 \mathrm{~nm})$ & {$\left[\mathrm{NO}_{2}-\mathrm{HPA}\right]$} & $(\%)$ \\
\hline 1 & 0 & 0.2237 & 50 & 100 \\
\hline 2 & 20 & 0.174486 & 40 & 78 \\
\hline 3 & 40 & 0.138694 & 31 & 62 \\
\hline 4 & 60 & 0.114087 & 26 & 51 \\
\hline 5 & 80 & 0.100665 & 22 & 43 \\
\hline 6 & 100 & 0.093954 & 21 & 38 \\
\hline
\end{tabular}

${ }^{[a]}$ Absorbance

${ }^{[b]}$ Concentration of $\mathrm{NO}_{2}$-HPA by using the following

$\mathrm{A}=\epsilon \times[\mathrm{C}] \times 1 ;[\mathrm{C}]=\mathrm{A} / \epsilon \times[\mathrm{C}] \times 1$

$[C]=0.2237 / 4400=5.0568 \times 10^{-5}$ or $50 \mu \mathrm{M}$

${ }^{[c]} 40 \mu \mathrm{M}=100 \%$;

$40 \mu \mathrm{M}=50 \times 40 / 100=78 \%$ 
Figure S-1. Plots obtained for 2. The concentration of PN was fixed to $50 \mu \mathrm{M}$. (See Table 1)

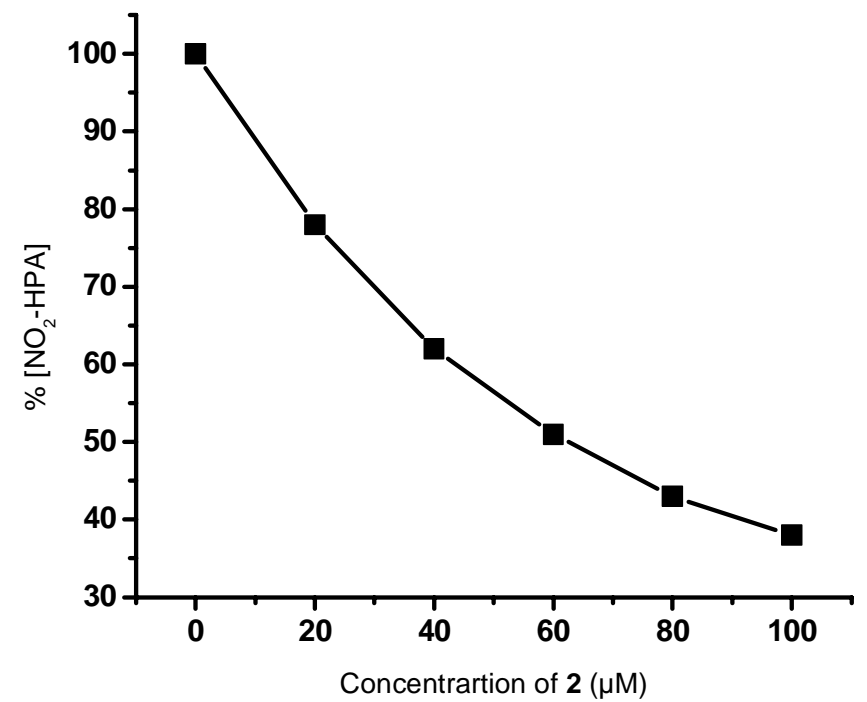

$\mathrm{IC}_{50}=63 \mu \mathrm{M}$ for Ebselen (2) 
Table 2: Concentration of $\mathrm{NO}_{2}$-HPA at various concentration of selenide (14)

\begin{tabular}{|l|l|c|c|c|}
\hline Sr. No. & $\mathbf{1 4}[\mathrm{C}] \mu \mathrm{M}$ & $\mathrm{A}(430 \mathrm{~nm})$ & {$\left[\mathrm{NO}_{2}-\mathrm{HPA}\right]$} & $(\%)$ \\
\hline 1 & 0 & 0.2225 & 50 & 100 \\
\hline 2 & 10 & 0.2092 & 48 & 94 \\
\hline 3 & 20 & 0.1980 & 45 & 89 \\
\hline 4 & 30 & 0.1869 & 42 & 84 \\
\hline 5 & 40 & 0.1802 & 41 & 81 \\
\hline 6 & 50 & 0.1736 & 39 & 78 \\
\hline 7 & 60 & 0.1646 & 37 & 74 \\
\hline 8 & 80 & 0.1558 & 35 & 70 \\
\hline 9 & 100 & 0.1424 & 32 & 64 \\
\hline 10 & 120 & 0.1223 & 28 & 55 \\
\hline 11 & 140 & 0.1068 & 24 & 48 \\
\hline 12 & 160 & 0.1001 & 22 & 45 \\
\hline
\end{tabular}

Figure S-2. Plots obtained for 14. The concentration of PN was fixed to $50 \mu \mathrm{M}$. (See Table 2)

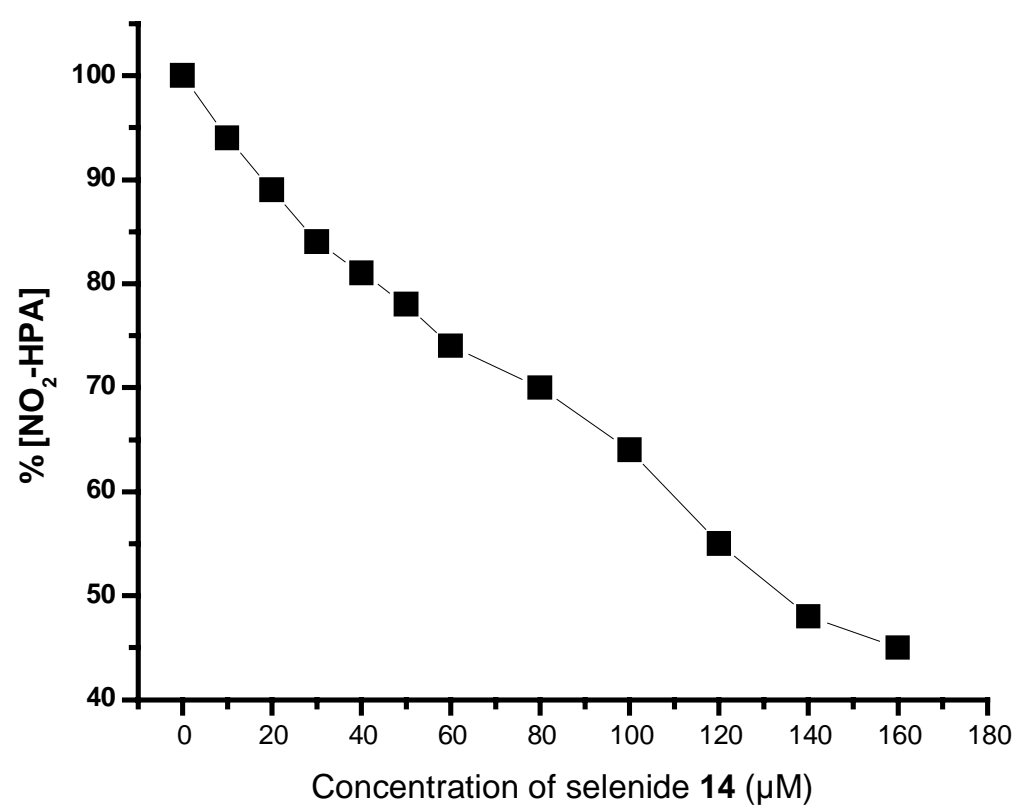

$\mathrm{IC}_{50}=134 \mu \mathrm{M}$ for selenide (14) 
Table 3: Concentration of $\mathrm{NO}_{2}-\mathrm{HPA}$ at various concentration of selenide (20)

\begin{tabular}{|l|l|c|l|c|}
\hline Sr. No. & $(\mathbf{2 0})[\mathrm{C}] \mu \mathrm{M}$ & $\mathrm{A}(430 \mathrm{~nm})$ & {$\left[\mathrm{NO}_{2}\right.$-HPA $]$} & $(\%)$ \\
\hline 1 & 0 & 0.2219 & 50 & 100 \\
\hline 2 & 10 & 0.2086 & 47 & 94 \\
\hline 3 & 20 & 0.1842 & 42 & 83 \\
\hline 4 & 30 & 0.1664 & 38 & 75 \\
\hline 5 & 40 & 0.1331 & 32 & 60 \\
\hline 6 & 50 & 0.0910 & 17 & 41 \\
\hline 7 & 60 & 0.064 & 14 & 29 \\
\hline
\end{tabular}

Figure S-3. Plots obtained for 20. The concentration of PN was fixed to $50 \mu \mathrm{M}$. (See Table 3)

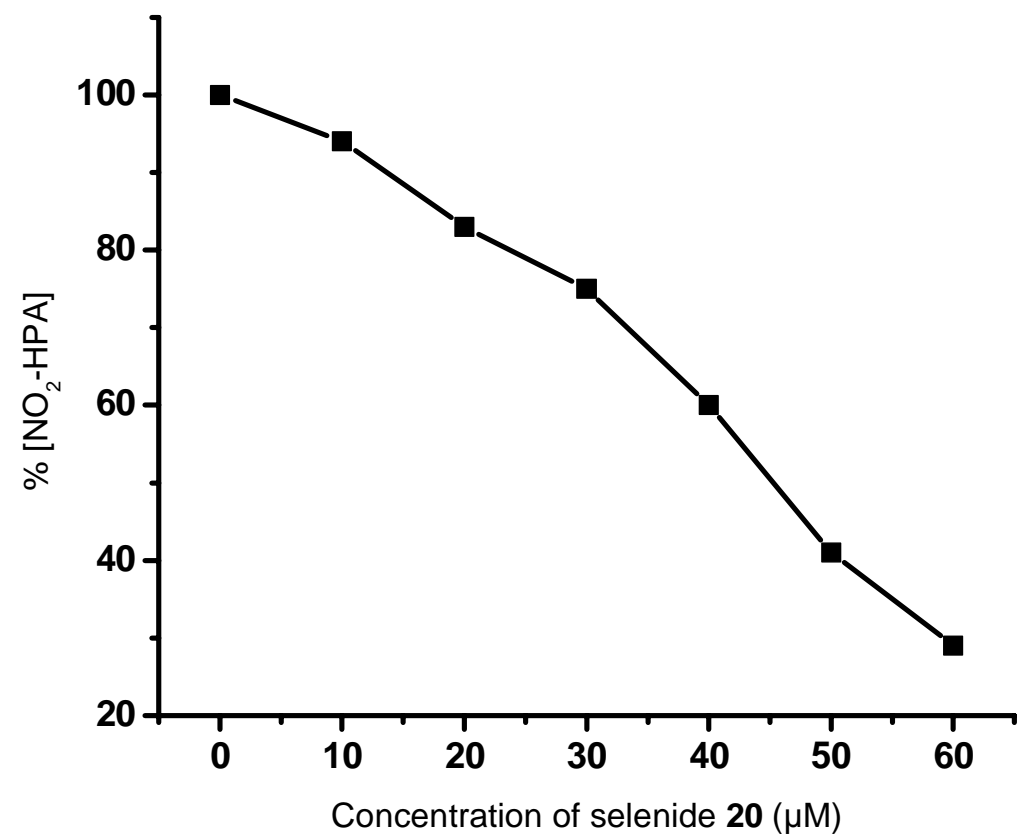

$\mathrm{IC}_{50}=43 \mu \mathrm{M}$ for selenide (20) 
Table 4. Concentration of $\mathrm{NO}_{2}-\mathrm{HPA}$ at various concentration of selenide (21)

\begin{tabular}{|l|l|l|l|c|}
\hline Sr. No. & $\mathbf{2 1}[\mathrm{C}] \mu \mathrm{M}$ & $\mathrm{A}(430 \mathrm{~nm})$ & $\begin{array}{l}{\left[\mathrm{NO}_{2}-\mathrm{HPA}\right]} \\
(\mu \mathrm{M})\end{array}$ & $(\%)$ \\
\hline 1 & 0 & 0.2343 & 53 & 100 \\
\hline 2 & 10 & 0.2132 & 48 & 91 \\
\hline 3 & 20 & 0.1851 & 46 & 79 \\
\hline 4 & 30 & 0.1476 & 33 & 63 \\
\hline 5 & 40 & 0.0773 & 18 & 33 \\
\hline 6 & 50 & 0.0609 & 14 & 26 \\
\hline 7 & 60 & 0.0515 & 12 & 22 \\
\hline
\end{tabular}

Figure S-4. Plots obtained for 21. The concentration of PN was fixed to $50 \mu \mathrm{M}$ and the concentration of selenide (21) was vary 0 to $150 \mu \mathrm{M}$ (See Table 4)

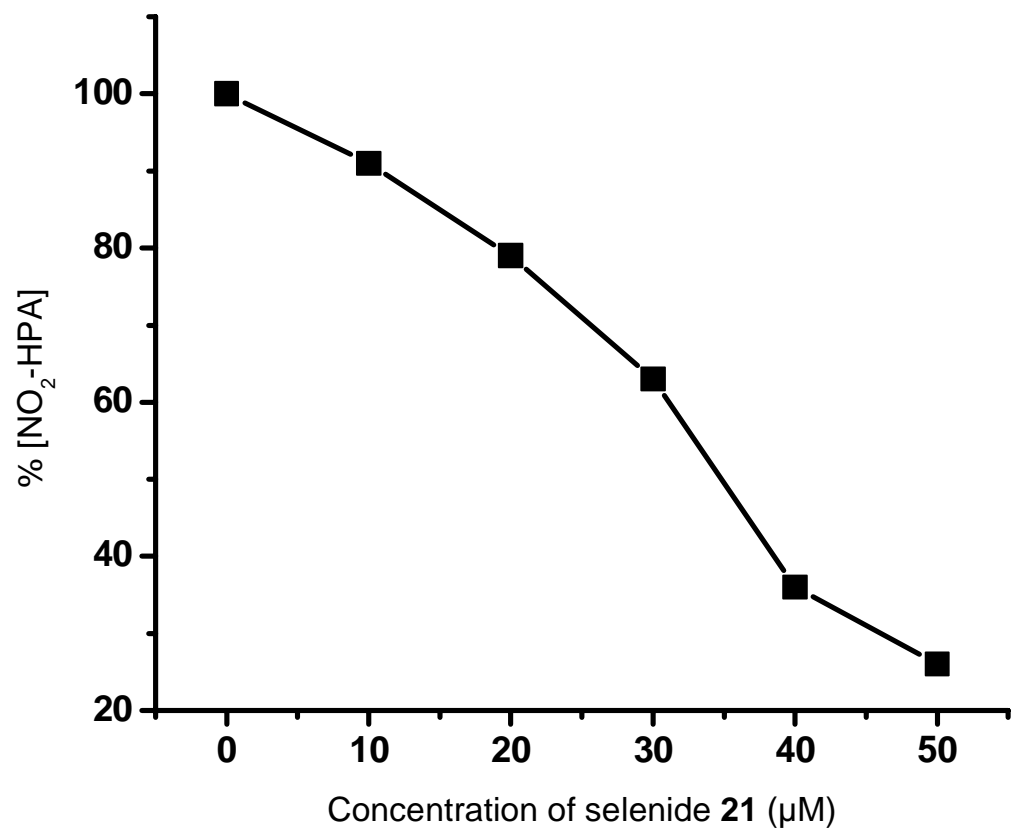

$\mathrm{IC}_{50}=34 \mu \mathrm{M}$ for selenide (21) 
Table 5. Concentration of $\mathrm{NO}_{2}-\mathrm{HPA}$ at various concentration of selenide (22)

\begin{tabular}{|l|l|l|l|c|}
\hline Sr. No. & $(\mathbf{2 2})[\mathrm{C}] \mu \mathrm{M}$ & $\mathrm{A}(430 \mathrm{~nm})$ & {$\left[\mathrm{NO}_{2}-\mathrm{HPA}\right]$} & $(\%)$ \\
\hline 1 & 0 & 0.2317 & 52 & 100 \\
\hline 2 & 10 & 0.183 & 42 & 79 \\
\hline 3 & 20 & 0.1506 & 34 & 65 \\
\hline 4 & 30 & 0.0996 & 22 & 43 \\
\hline 5 & 40 & 0.0811 & 18 & 35 \\
\hline 6 & 50 & 0.0556 & 12 & 24 \\
\hline 7 & 60 & 0.0579 & 13 & 25 \\
\hline
\end{tabular}

Figure S-5. Plots obtained for 22. The concentration of PN was fixed to $50 \mu \mathrm{M}$. (See Table 5)

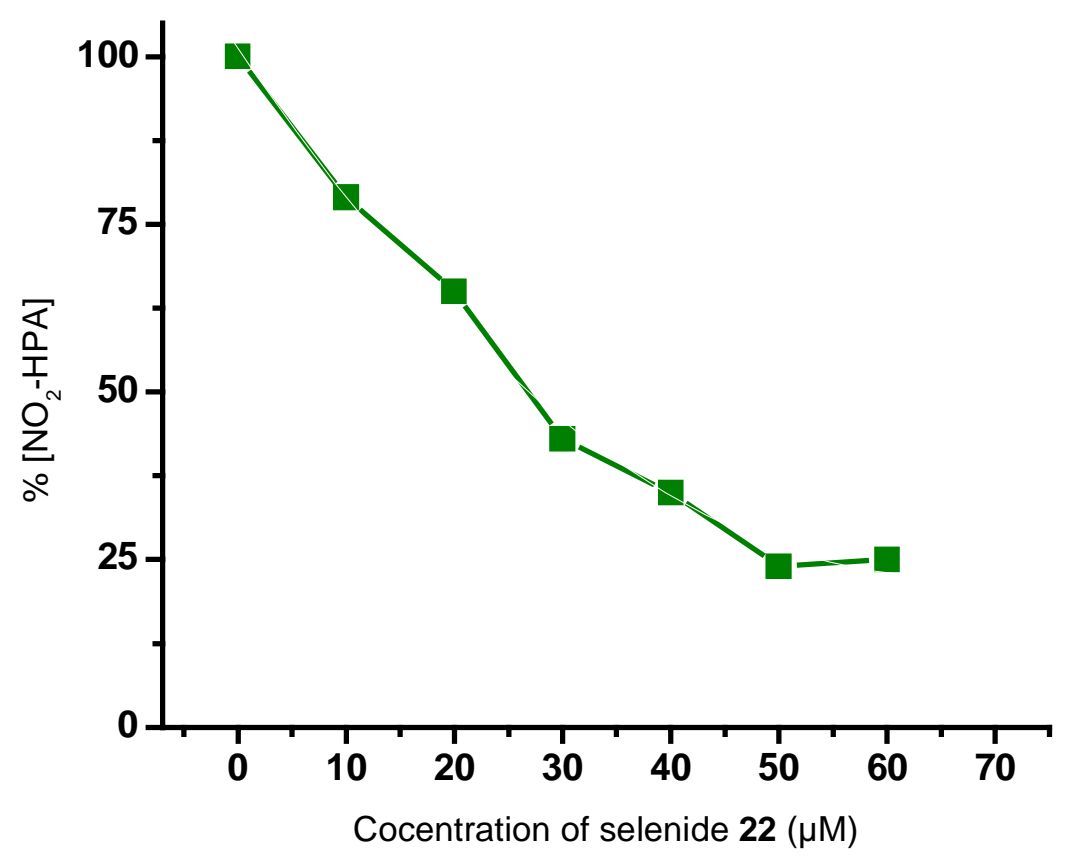

$\mathrm{IC}_{50}=28 \mu \mathrm{M}$ for selenide (22) 
Table 6. Concentration of $\mathrm{NO}_{2}$-HPA at various concentration of selenide (24)

\begin{tabular}{|l|l|l|l|c|}
\hline Sr. No. & $(\mathbf{2 4})[\mathrm{C}] \mu \mathrm{M}$ & $\mathrm{A}(430 \mathrm{~nm})$ & {$\left[\mathrm{NO}_{2}-\mathrm{HPA}\right]$} & $(\%)$ \\
\hline 1 & 0 & 0.2194 & 50 & 100 \\
\hline 2 & 10 & 0.2084 & 47 & 95 \\
\hline 3 & 20 & 0.1908 & 43 & 87 \\
\hline 4 & 30 & 0.1644 & 37 & 75 \\
\hline 5 & 40 & 0.1535 & 34 & 70 \\
\hline 6 & 50 & 0.1162 & 26 & 53 \\
\hline 7 & 60 & 0.1009 & 23 & 46 \\
\hline
\end{tabular}

Figure S-6. Plots obtained for 24. The concentration of PN was fixed to $50 \mu \mathrm{M}$. (See Table 6)

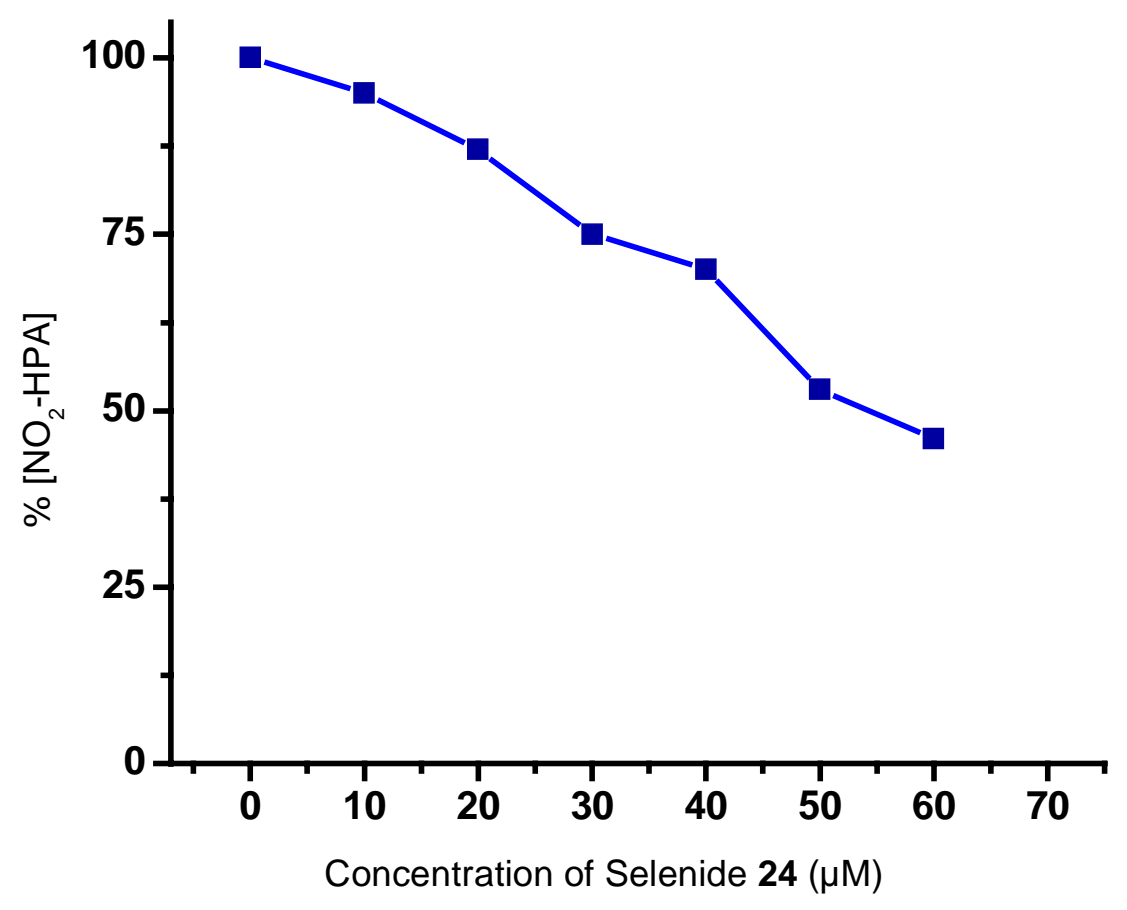

$\mathrm{IC}_{50}=54 \mu \mathrm{M}$ for selenide (24) 
Table 7: Concentration of $\mathrm{NO}_{2}$-HPA at various concentration of selenide (26)

\begin{tabular}{|l|l|c|c|c|}
\hline Sr. No. & $(\mathbf{2 6})[\mathrm{C}] \mu \mathrm{M}$ & $\mathrm{A}(430 \mathrm{~nm})$ & {$\left[\mathrm{NO}_{2}-\mathrm{HPA}\right]$} & $(\%)$ \\
\hline 1 & 0 & 0.1987 & 45 & 100 \\
\hline 2 & 20 & 0.1689 & 38 & 85 \\
\hline 3 & 40 & 0.1390 & 31 & 70 \\
\hline 4 & 60 & 0.1132 & 26 & 57 \\
\hline 5 & 80 & 0.0973 & 22 & 49 \\
\hline 6 & 100 & 0.0834 & 19 & 42 \\
\hline 7 & 120 & 0.0934 & 21 & 47 \\
\hline
\end{tabular}

Figure S-7. Plots obtained for 26. The concentration of PN was fixed to $50 \mu \mathrm{M}$. (See Table 7)

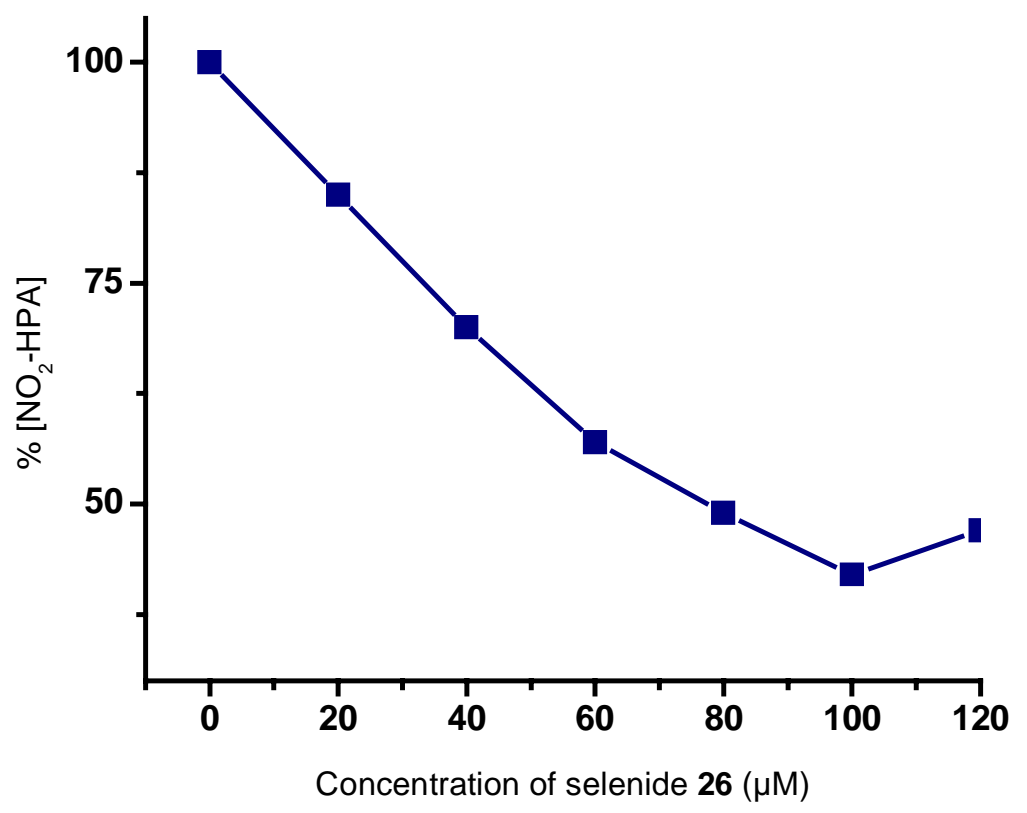

$\mathrm{IC}_{50}=80 \mu \mathrm{M}$ for selenide (26) 
Table 8: Concentration of $\mathrm{NO}_{2}$-HPA at various concentration of selenide(27)

\begin{tabular}{|l|c|c|c|c|}
\hline Sr. No. & $(\mathbf{2 7})[\mathrm{C}] \mu \mathrm{M}$ & $\mathrm{A}(430 \mathrm{~nm})$ & {$\left[\mathrm{NO}_{2}\right.$-HPA $]$} & $(\%)$ \\
\hline 1 & 0 & 0.2419 & 55 & 100 \\
\hline 2 & 20 & 0.2080 & 47 & 86 \\
\hline 3 & 40 & 0.1693 & 38 & 70 \\
\hline 4 & 60 & 0.1403 & 32 & 58 \\
\hline 5 & 80 & 0.1137 & 26 & 47 \\
\hline 6 & 100 & 0.1040 & 23 & 43 \\
\hline 7 & 120 & 0.1088 & 24 & 45 \\
\hline
\end{tabular}

Figure S-8. Plots obtained for 27. The concentration of PN was fixed to $50 \mu \mathrm{M}$. (See Table 8)

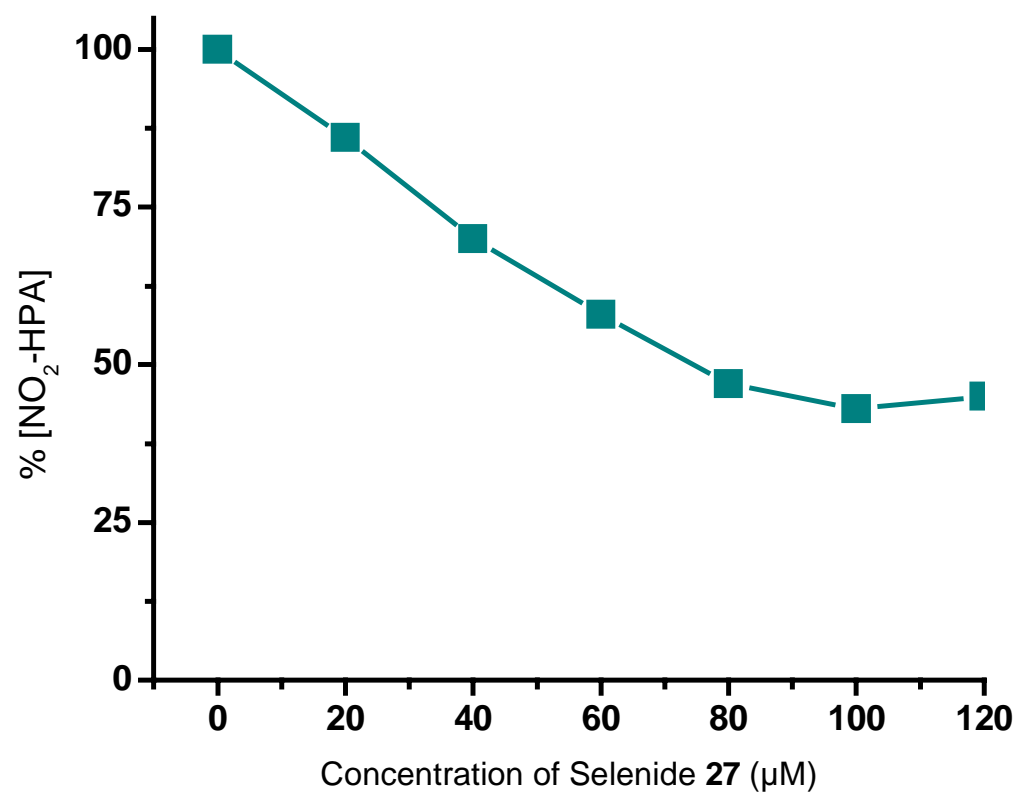

$\mathrm{IC}_{50}=72 \mu \mathrm{M}$ for selenide (27) 
Table 9. Concentration of $\mathrm{NO}_{2}-\mathrm{HPA}$ at various concentration of selenide (28)

\begin{tabular}{|l|l|c|c|c|}
\hline Sr. No. & $(\mathbf{2 8})[\mathrm{C}] \mu \mathrm{M}$ & $\mathrm{A}(430 \mathrm{~nm})$ & {$\left[\mathrm{NO}_{2}-\mathrm{HPA}\right]$} & $(\%)$ \\
\hline 1 & 0 & 0.2457 & 56 & 100 \\
\hline 2 & 20 & 0.1892 & 43 & 77 \\
\hline 3 & 40 & 0.1474 & 33 & 60 \\
\hline 4 & 60 & 0.1081 & 24 & 44 \\
\hline 5 & 80 & 0.0933 & 21 & 38 \\
\hline 6 & 100 & 0.0958 & 22 & 39 \\
\hline
\end{tabular}

Figure S-9. Plots obtained for 28. The concentration of PN was fixed to $50 \mu \mathrm{M}$. (See Table 9)

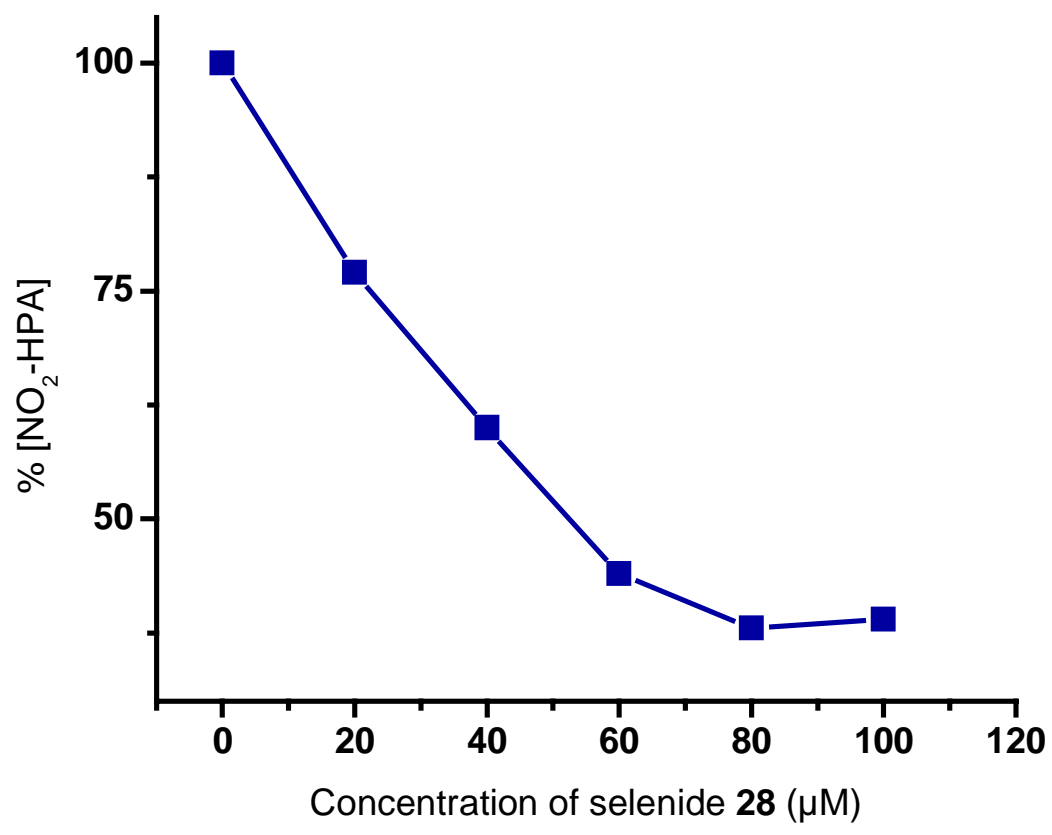

$\mathrm{IC}_{50}=52 \mu \mathrm{M}$ for selenide $(\mathbf{2 8})$ 
Table 10. Concentration of $\mathrm{NO}_{2}-4-\mathrm{HPA}$ at various concentration of testing compound (29)

\begin{tabular}{|l|l|c|c|c|}
\hline Sr. No. & $\mathbf{2 9}[\mathrm{C}] \mu \mathrm{M}$ & $\mathrm{A}(430 \mathrm{~nm})$ & {$\left[\mathrm{NO}_{2}-4-\mathrm{HPA}\right]$} & $(\%)$ \\
\hline 1 & 0 & 0.2297 & 52 & 100 \\
\hline 2 & 20 & 0.1975 & 45 & 86 \\
\hline 3 & 40 & 0.1630 & 37 & 71 \\
\hline 4 & 60 & 0.1378 & 31 & 60 \\
\hline 5 & 80 & 0.1194 & 27 & 52 \\
\hline 6 & 100 & 0.0987 & 22 & 43 \\
\hline 7 & 120 & 0.0827 & 18 & 36 \\
\hline 8 & 150 & 0.0896 & 20 & 39 \\
\hline
\end{tabular}

Figure S-10. Plots obtained for 29. The concentration of PN was fixed to $50 \mu \mathrm{M}$ and the concentration of selenide (29) was vary 0 to $150 \mu \mathrm{M}$ (See Table 10)

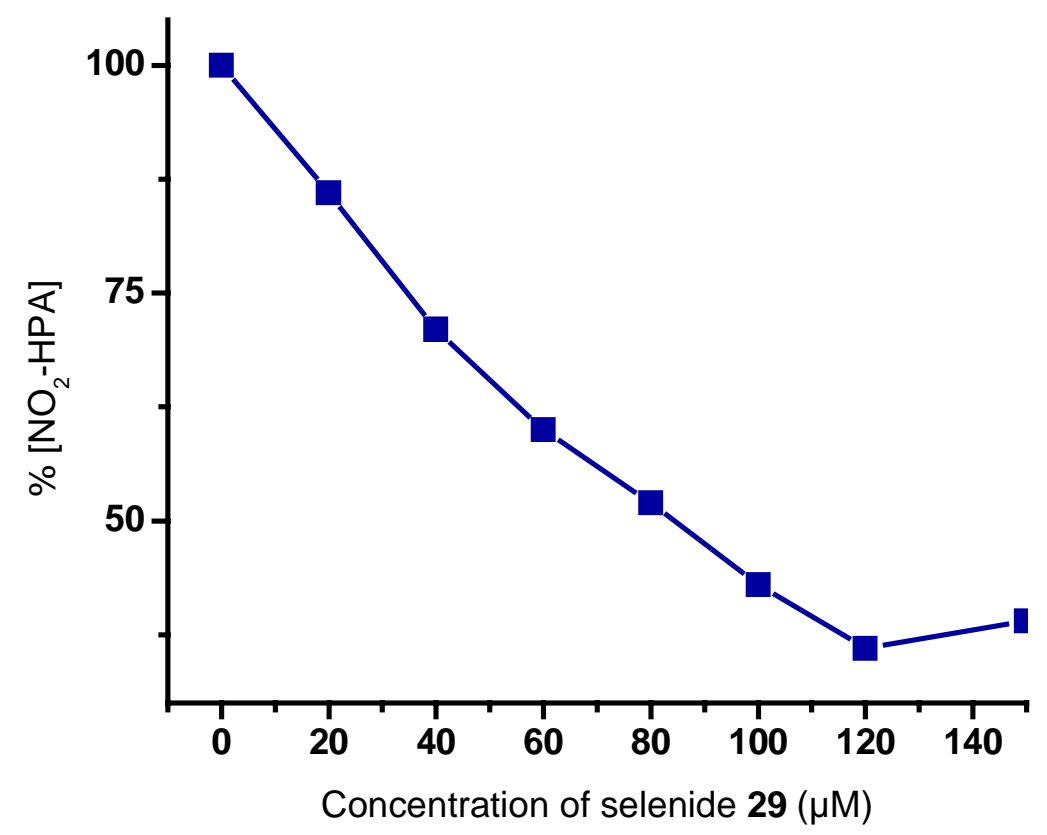

$\mathrm{IC}_{50}=84 \mu \mathrm{M}$ for selenide (29) 
Table 11. Concentration of $\mathrm{NO}_{2}$-HPA at various concentration of selenide (30)

\begin{tabular}{|l|l|c|c|c|}
\hline Sr. No. & $\mathbf{3 0}[\mathrm{C}] \mu \mathrm{M}$ & $\mathrm{A}(430 \mathrm{~nm})$ & {$\left[\mathrm{NO}_{2}-\mathrm{HPA}\right]$} & $\%$ \\
\hline 1 & 0 & 0.2137 & 49 & 100 \\
\hline 2 & 20 & 0.1880 & 42 & 88 \\
\hline 3 & 40 & 0.1517 & 34 & 71 \\
\hline 4 & 60 & 0.1389 & 32 & 65 \\
\hline 5 & 80 & 0.1218 & 28 & 57 \\
\hline 6 & 100 & 0.0940 & 21 & 44 \\
\hline 7 & 120 & 0.0812 & 18 & 38 \\
\hline 8 & 150 & 0.0854 & 19 & 40 \\
\hline
\end{tabular}

Figure S-11. Plots obtained for 30. The concentration of PN was fixed to $50 \mu \mathrm{M}$. (See Table 11)

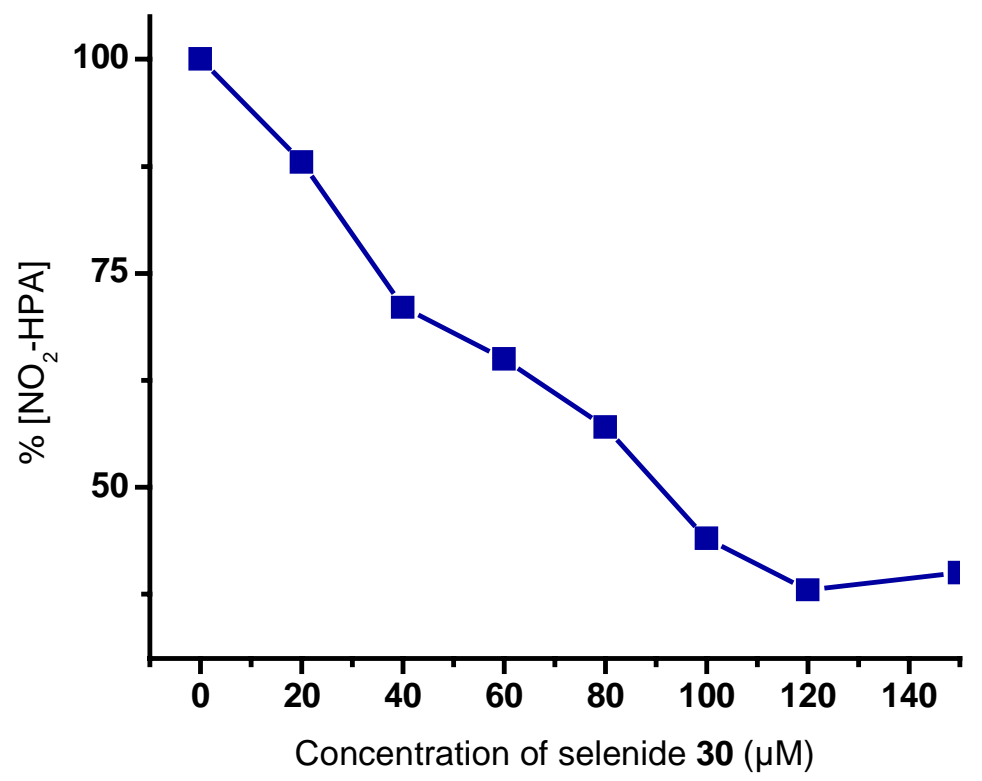

$\mathrm{IC}_{50}=90 \mu \mathrm{M}$ for selenide $\left.\mathbf{( 3 0}\right)$ 
Table 12. Concentration of $\mathrm{NO}_{2}$-HPA at various concentration of selenide (31)

\begin{tabular}{|l|l|c|c|c|}
\hline Sr. No. & $\mathbf{3 1}[\mathrm{C}] \mu \mathrm{M}$ & $\mathrm{A}(430 \mathrm{~nm})$ & {$\left[\mathrm{NO}_{2}-\mathrm{HPA}\right]$} & $(\%)$ \\
\hline 1 & 0 & 0.2118 & 48 & 100 \\
\hline 2 & 20 & 0.2033 & 46 & 96 \\
\hline 3 & 40 & 0.1694 & 38 & 80 \\
\hline 4 & 60 & 0.1355 & 30 & 64 \\
\hline 5 & 80 & 0.1186 & 27 & 56 \\
\hline 6 & 100 & 0.1080 & 24 & 51 \\
\hline 7 & 120 & 0.0847 & 19 & 40 \\
\hline 8 & 150 & 0.0762 & 17 & 36 \\
\hline
\end{tabular}

Figure S-12. Plots obtained for 31. The concentration of PN was fixed to $50 \mu \mathrm{M}$ and the concentration of selenide (31) was vary 0 to $150 \mu \mathrm{M}$ (See Table 12)

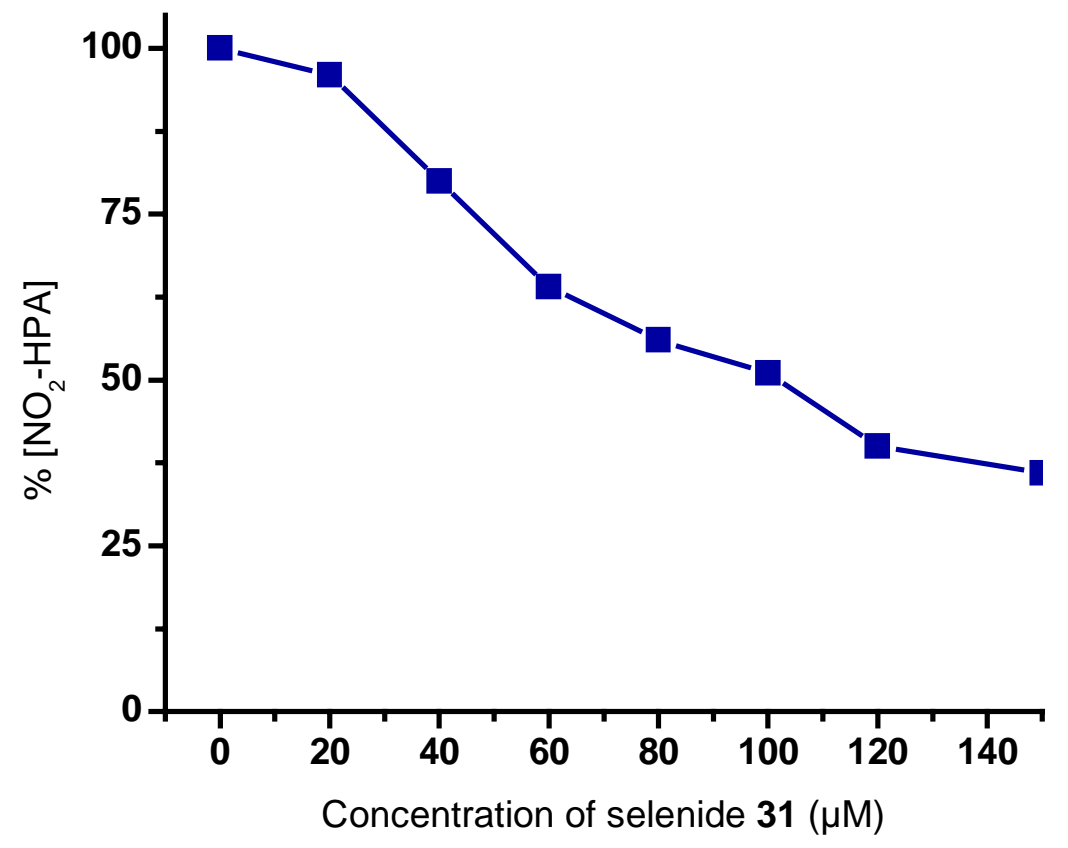

$\mathrm{IC}_{50}=102 \mu \mathrm{M}$ for selenide $(\mathbf{3 1})$ 
Figure S-13 ${ }^{77}$ Se NMR spectrum (300 MHz) spectrum of 21 in $\mathrm{CDCl}_{3}$

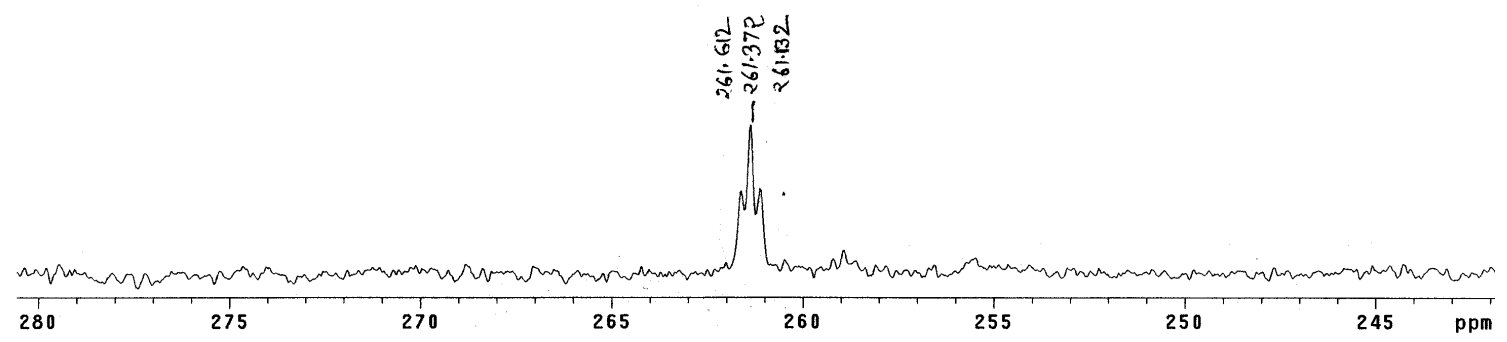

Figure S-14 ${ }^{77}$ Se NMR spectrum (300 MHz) spectrum of 22 in $\mathrm{CDCl}_{3}$

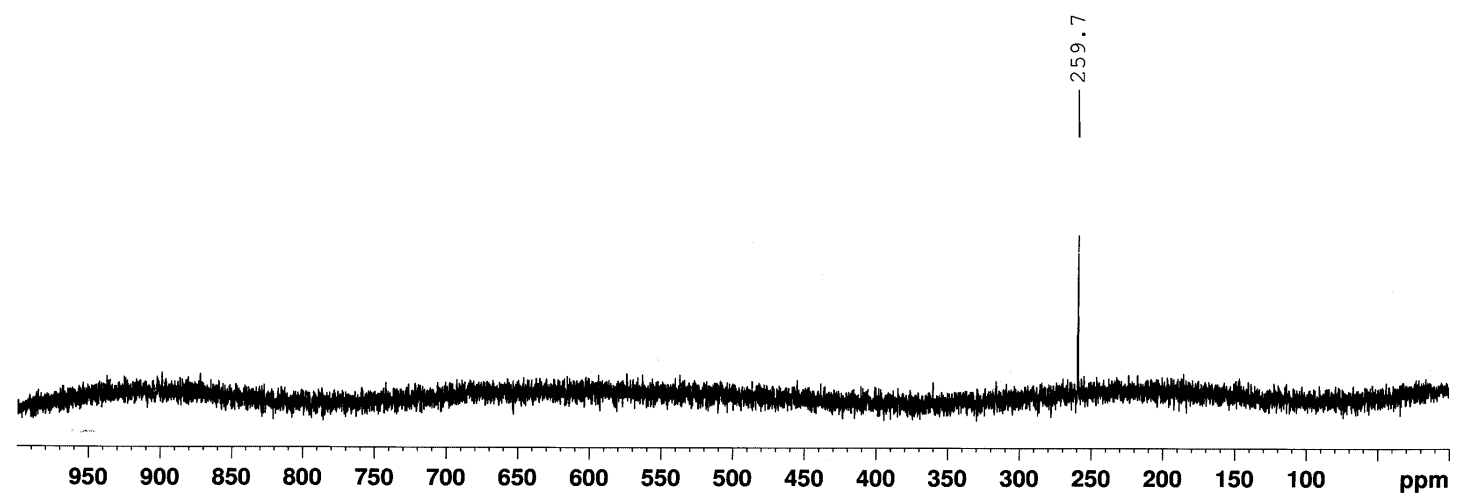


Figure S-15. ${ }^{77}$ Se NMR spectrum $(300 \mathrm{MHz})$ spectrum of 25 in $\mathrm{CDCl}_{3}$

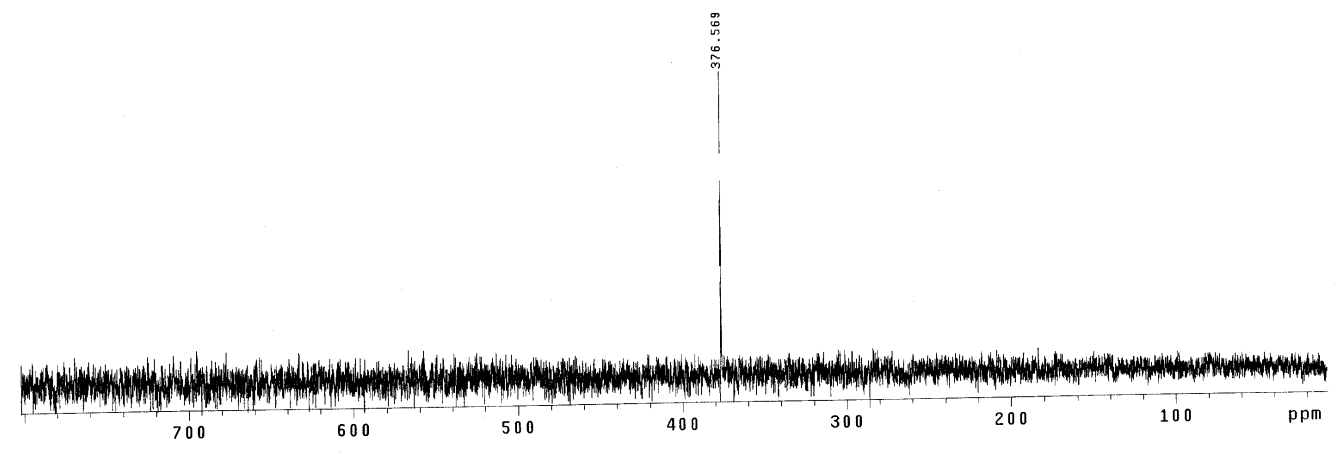

Figure S-16. ${ }^{77} \mathrm{Se} \mathrm{NMR}$ spectrum $(300 \mathrm{MHz})$ spectrum of 26 in $\mathrm{CDCl}_{3}$

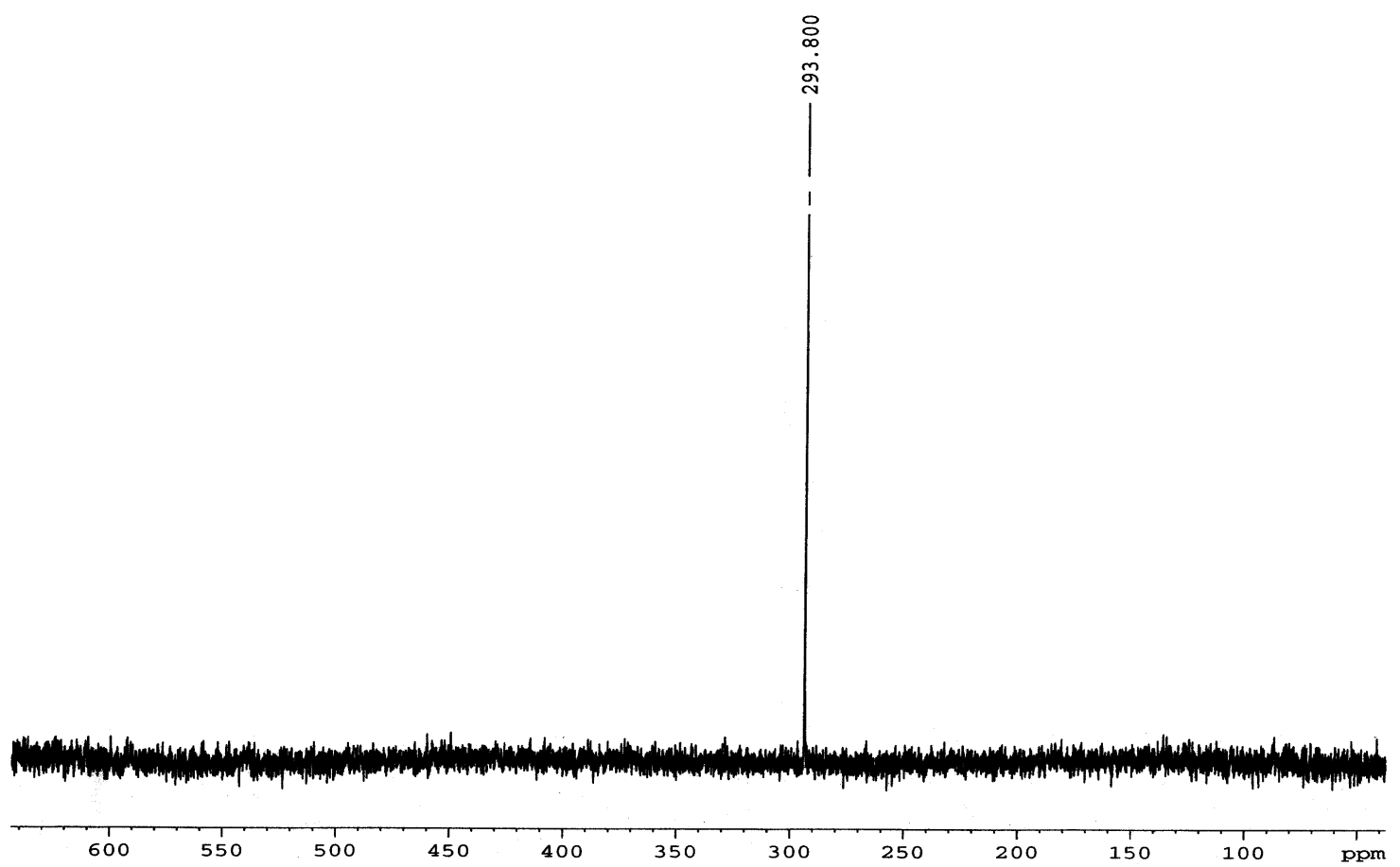


Figure S-17 ${ }^{77} \mathrm{Se}$ NMR spectrum (300 MHz) spectrum of 27 in $\mathrm{CDCl}_{3}$

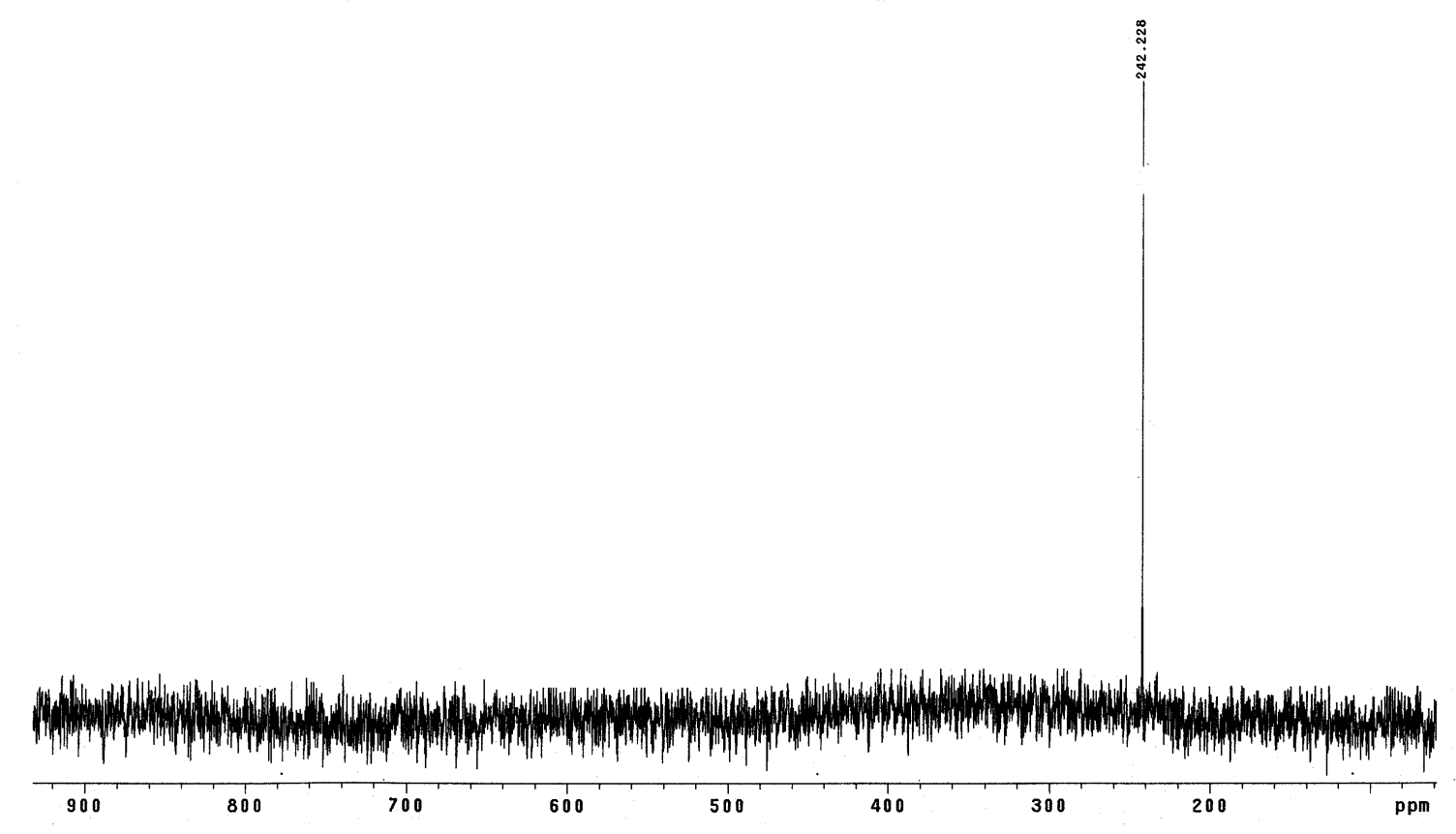


Figure S-18 ${ }^{77} \mathrm{Se}$ NMR spectrum (300 MHz) spectrum of 28 in $\mathrm{CDCl}_{3}$

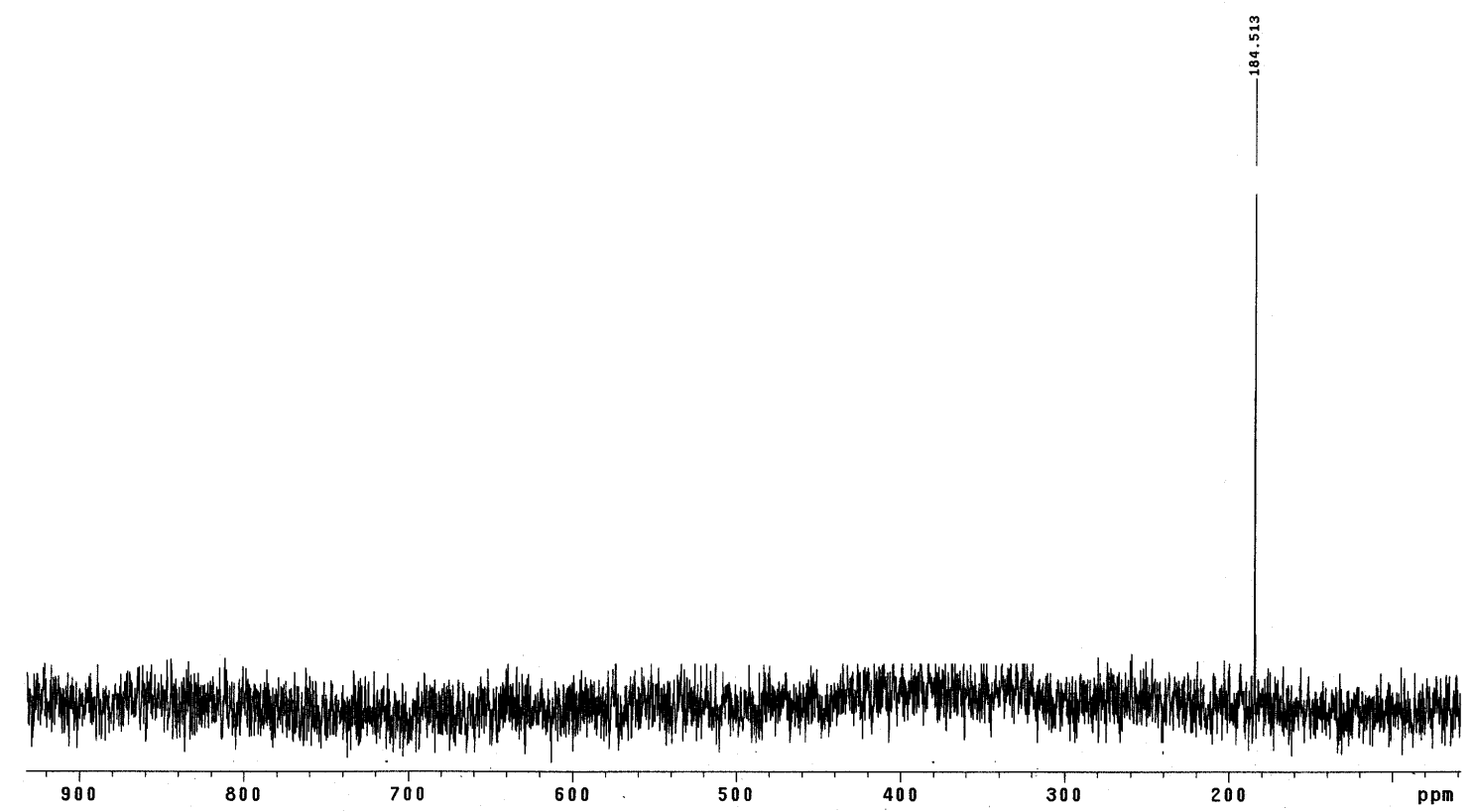

Figure S-19 ${ }^{77} \mathrm{Se}$ NMR spectrum $(300 \mathrm{MHz})$ spectrum of 29 in $\mathrm{CDCl}_{3}$

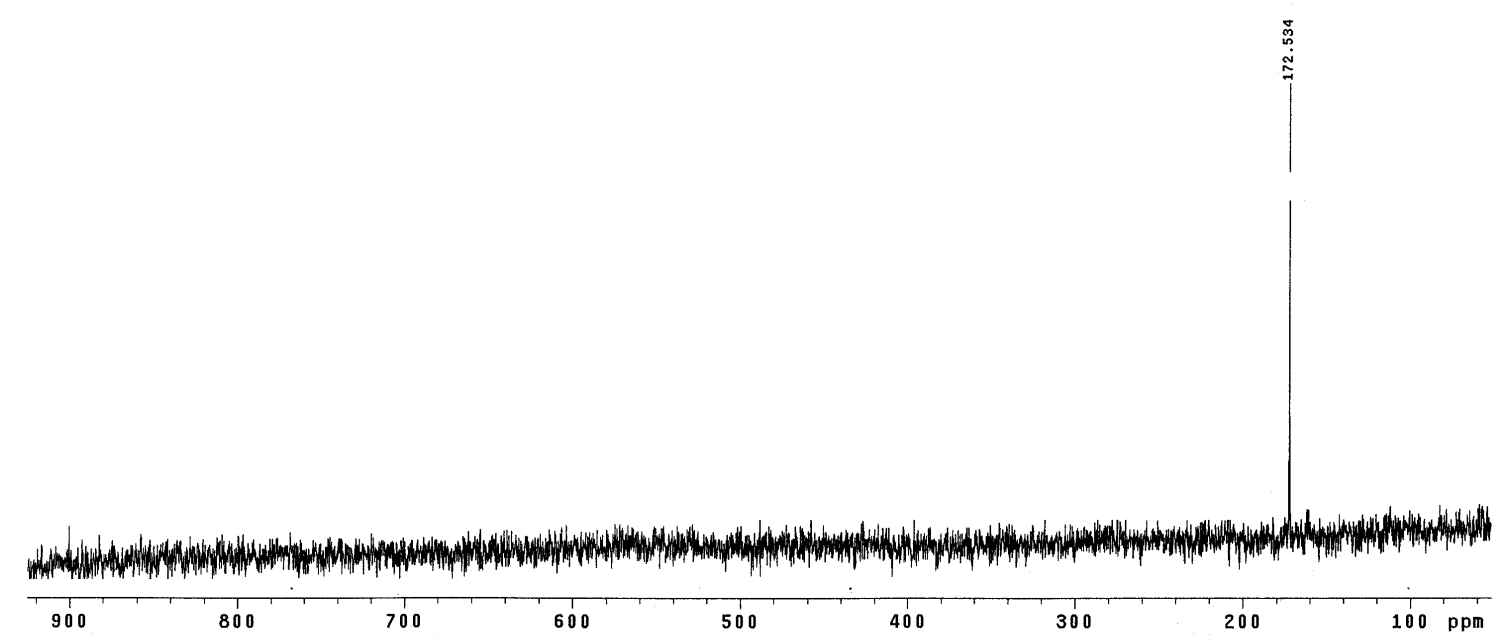


Figure S-20 ES-MS spectrum of 29 in $\mathrm{MeOH}$

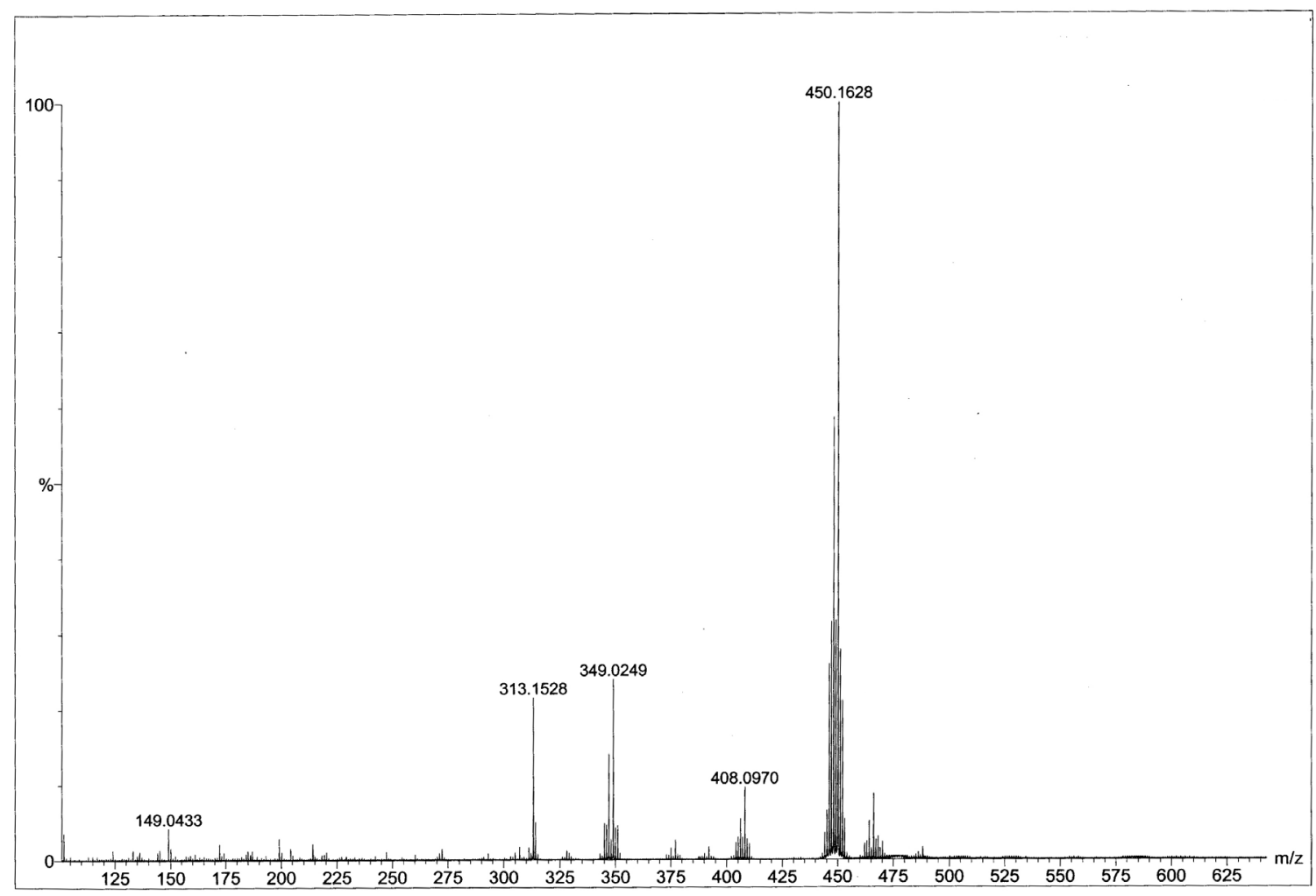

Molecular ion peak 450 correspond to selenide, $\mathrm{RSe}^{t} \mathrm{Bu}(\mathbf{2 9})$ 
Figure S-21 ${ }^{77} \mathrm{Se}$ NMR spectrum (300 MHz) spectrum of 30 in $\mathrm{CDCl}_{3}$

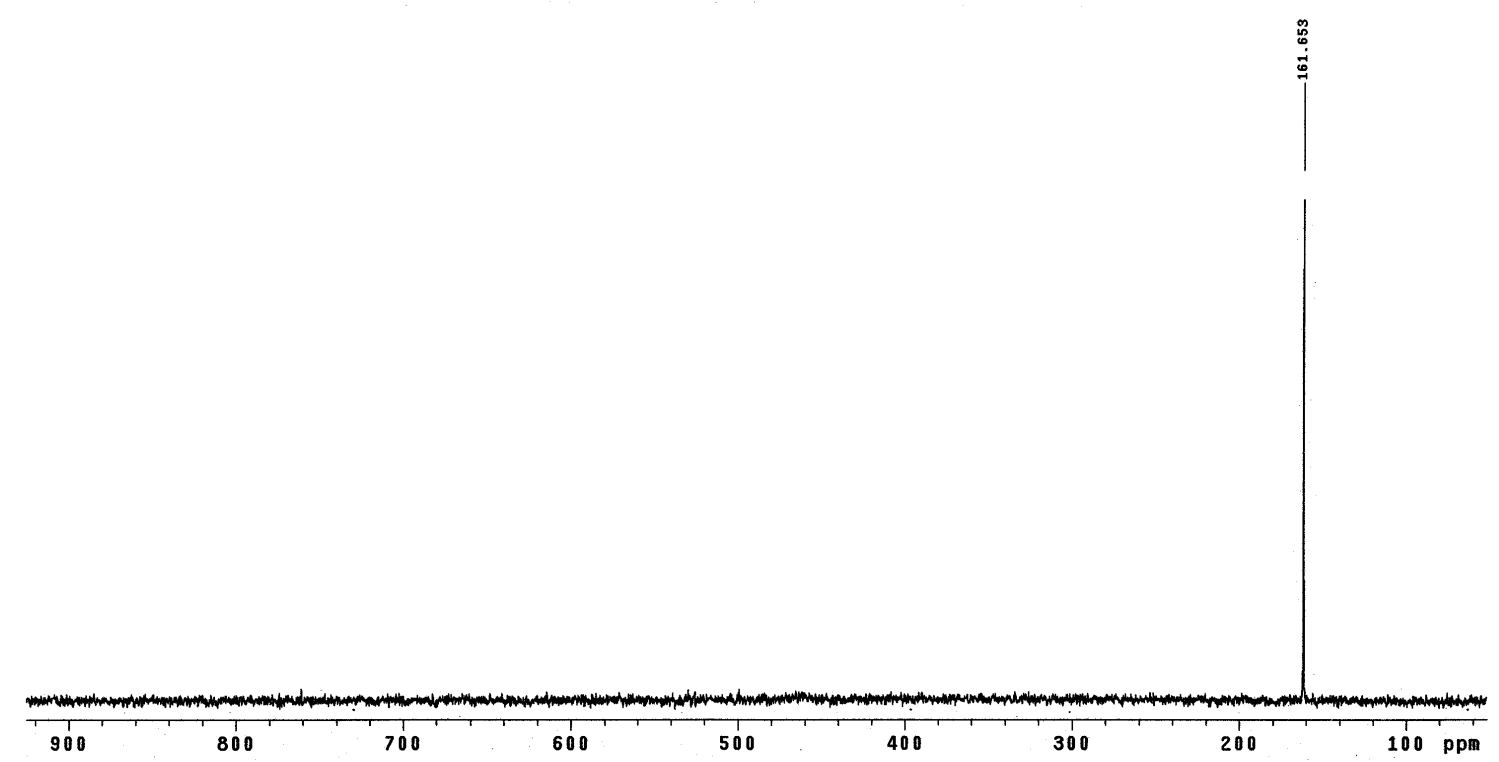

Figure S-22 ESMS spectrum of $\mathbf{3 0}$ in $\mathrm{MeOH}$

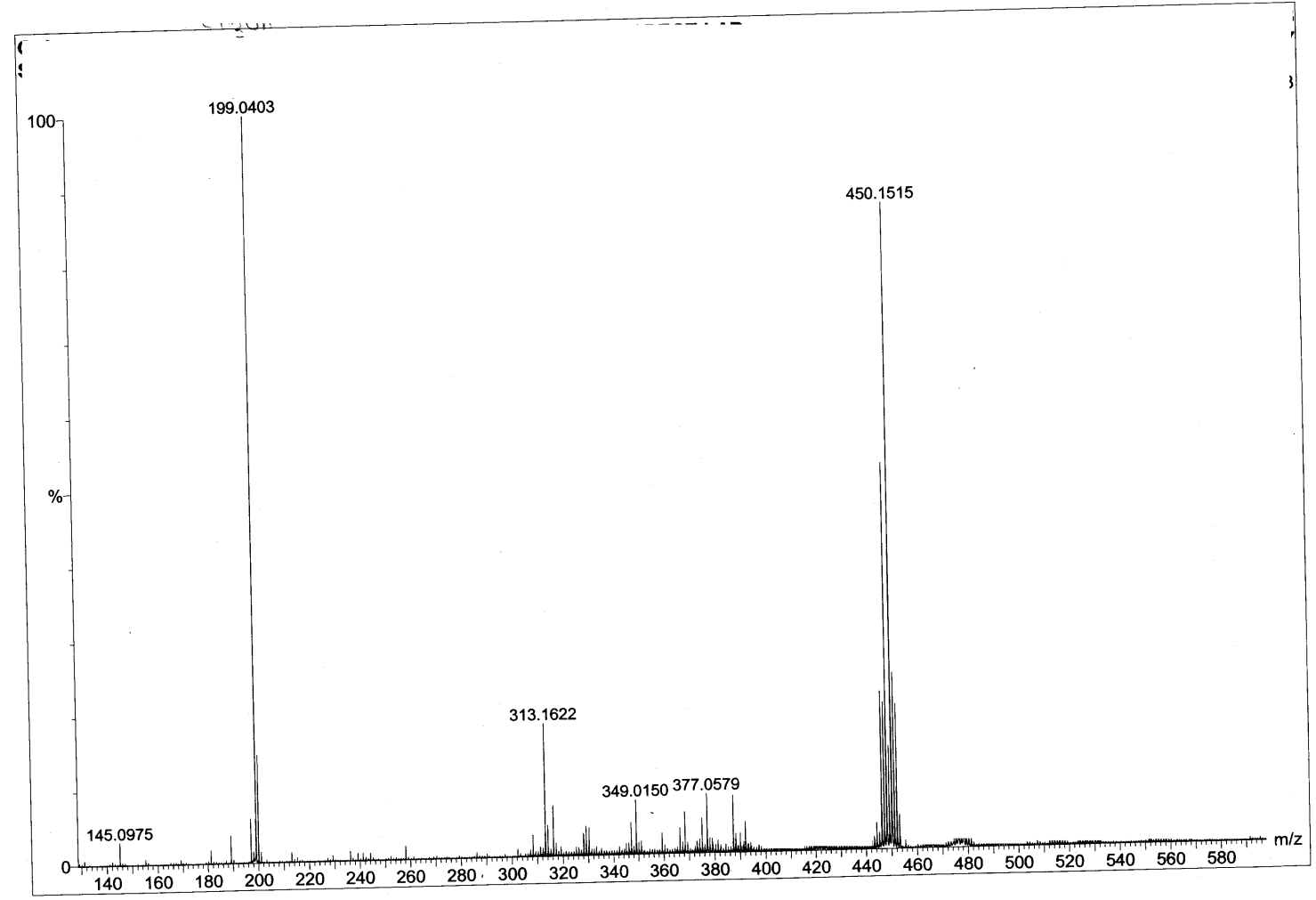

Molecular ion peak 450 correspond to $\mathrm{RSe}^{n} \mathrm{Bu}(\mathbf{3 0})$. 
Figure $\mathbf{S - 2 3}{ }^{77} \mathrm{Se} \mathrm{NMR}$ spectrum (300 MHz) spectrum of $\mathbf{3 1}$ in $\mathrm{CDCl}_{3}$

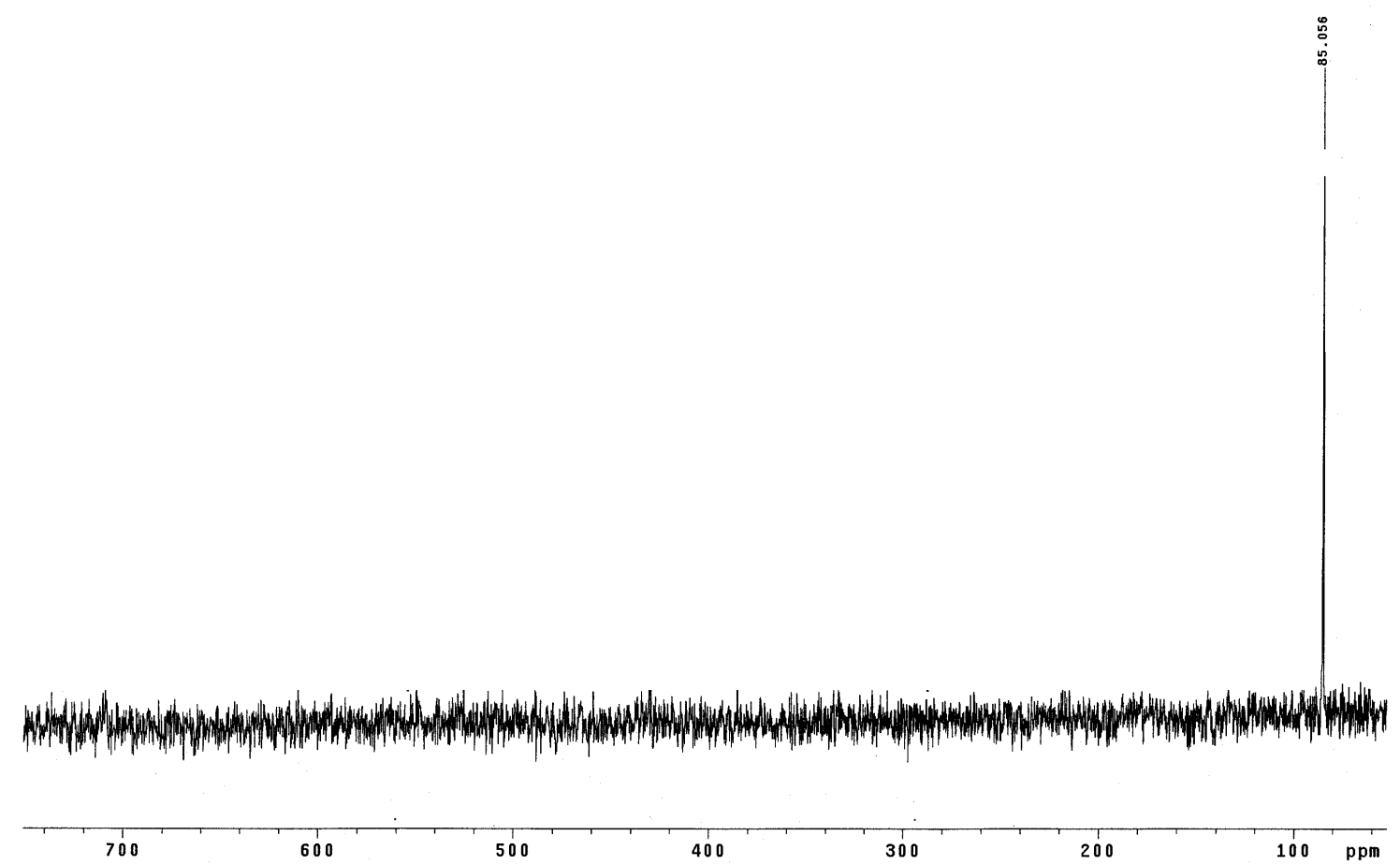


Figure S-24 ES-MS spectrum of isolated $\mathbf{3 1}$ in $\mathrm{MeOH}$

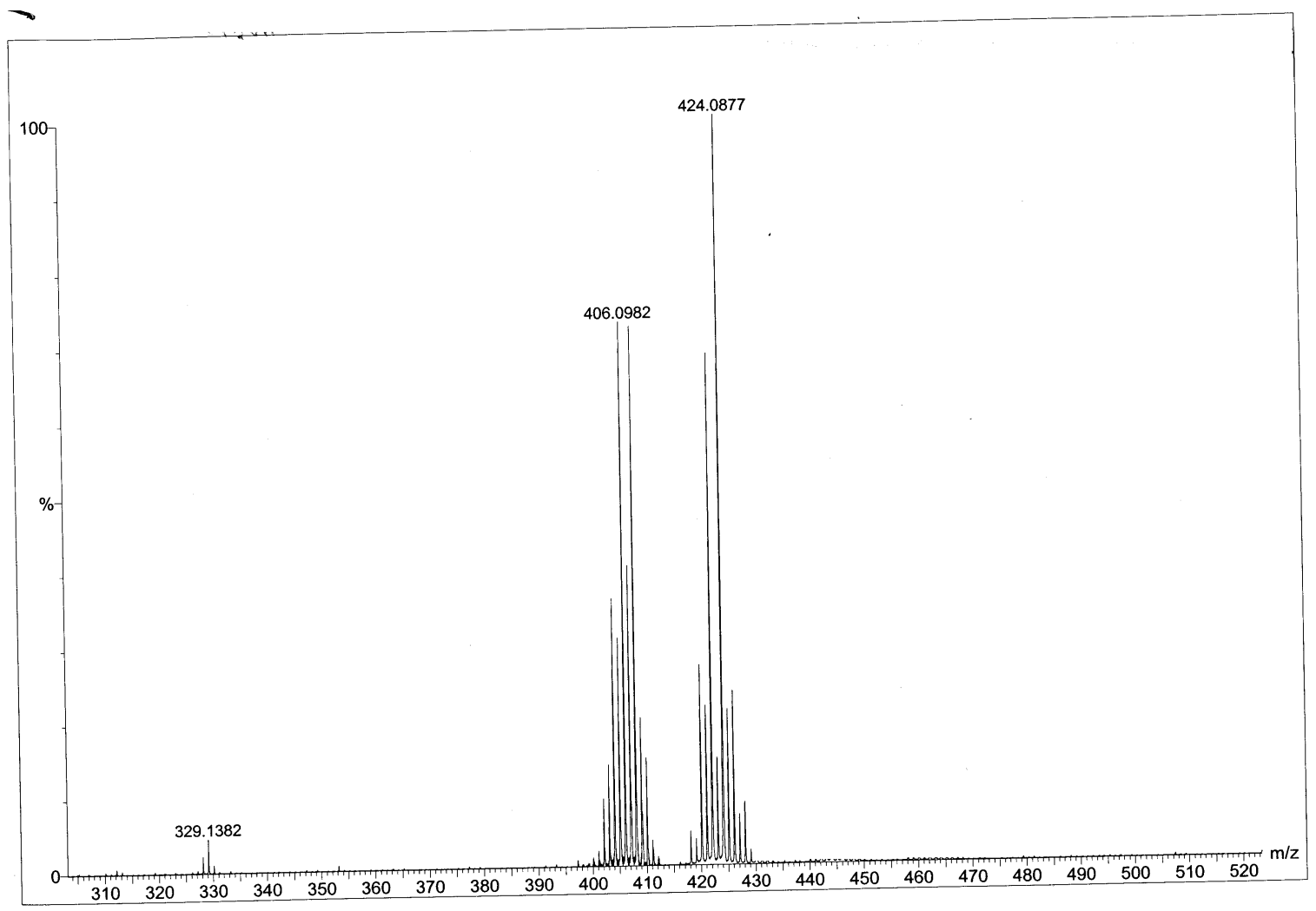

Molecular ion peaks 406, 424 correspond to selenide, $\mathrm{RSeMe}(\mathbf{3 1})$ and $\mathrm{RSeMe}+\mathrm{H}_{2} \mathrm{O}$ respectively 
Figure S-25. ES-MS of in situ generated selenoxide 13 in $\mathrm{MeOH}$

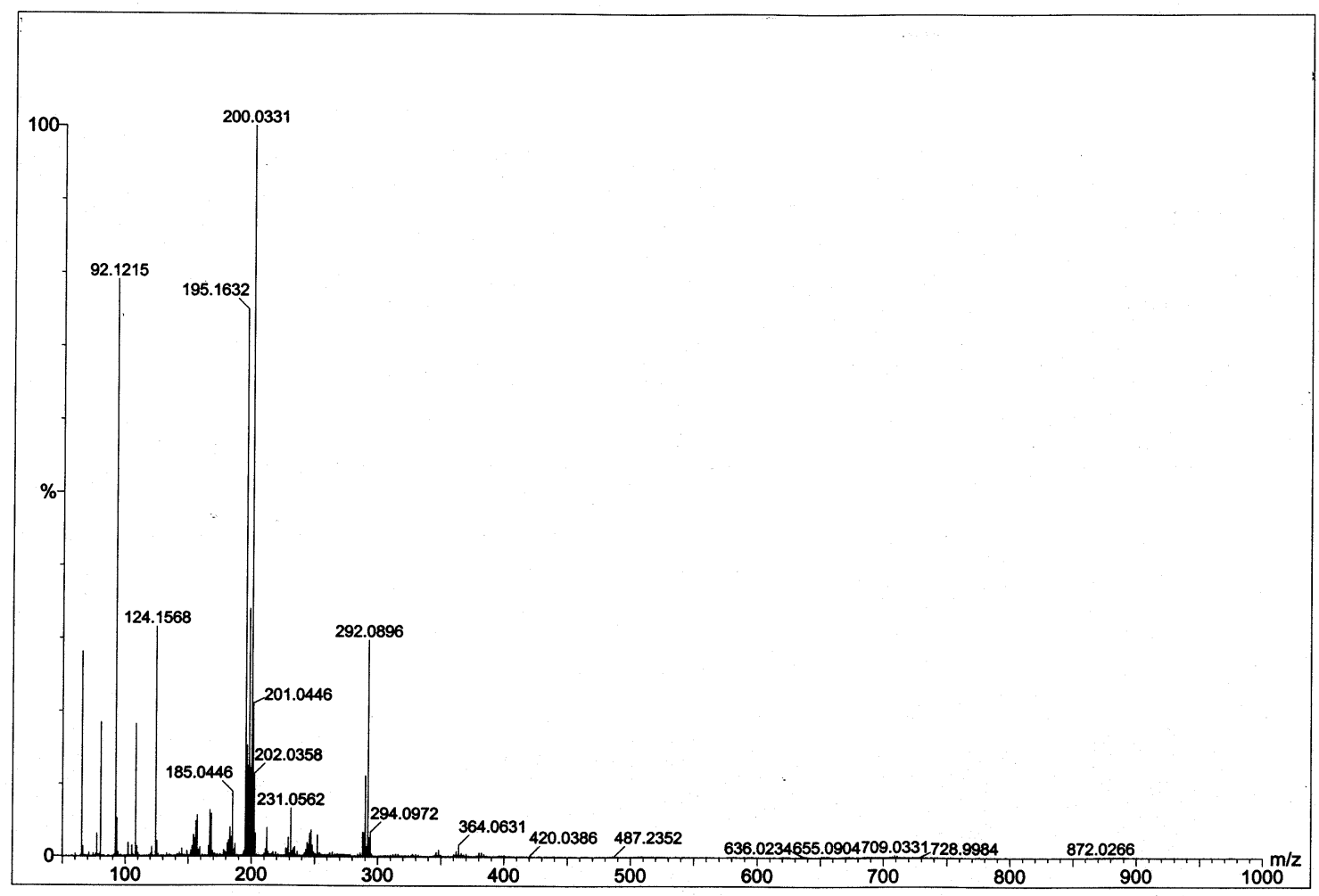

Molecular ion peak at 292 is due to Ebselen oxide (13). 
Figure S-26. ES-MS of in situ generated Ebselen oxide (13) in $\mathrm{MeOH}$ and expansion from Figure S-59.

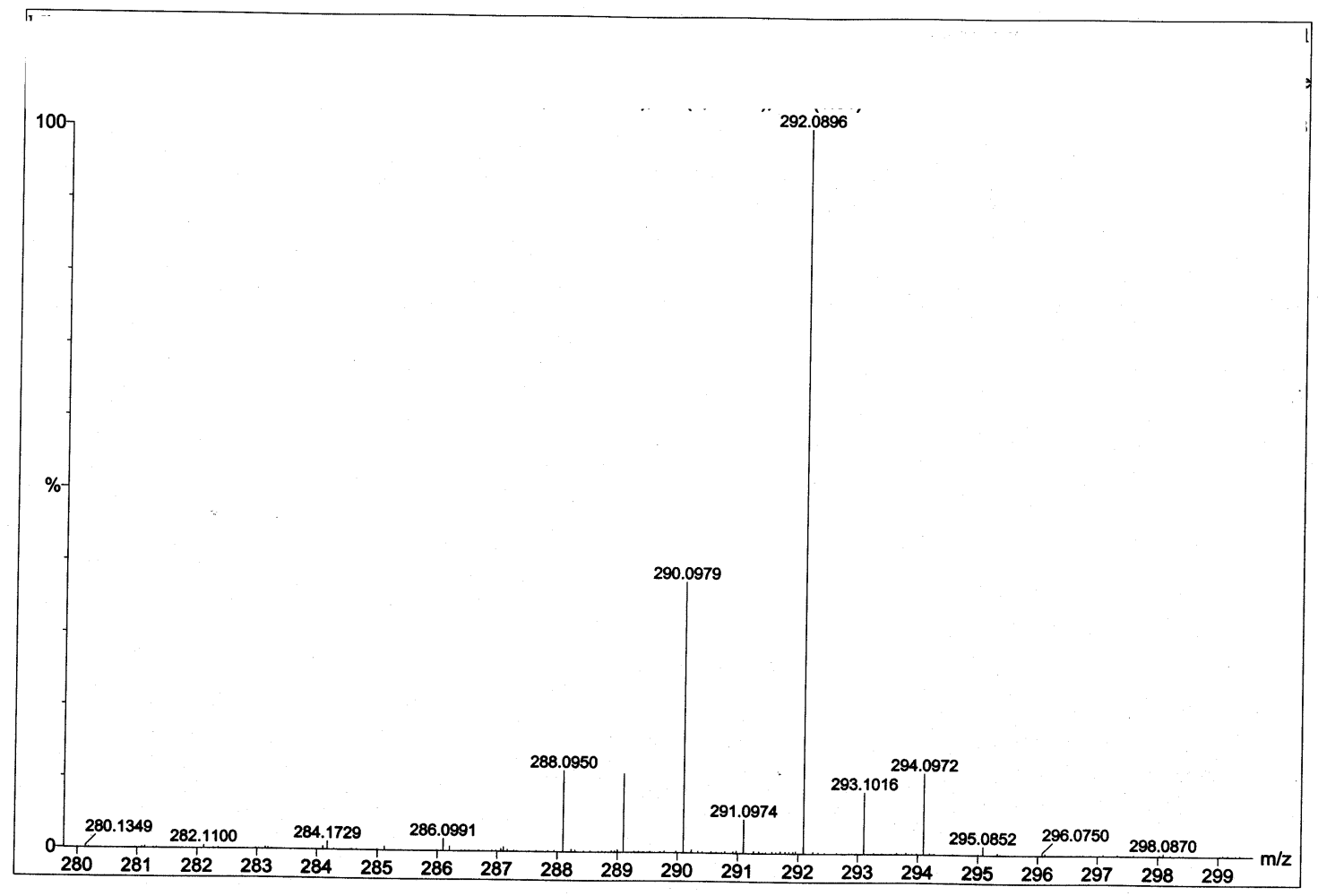


Figure S-27. ES-MS of in situ generated thioselenenate $(65$, calc MW = 400) and selenenylsulfide $(\mathbf{6 7}$; calc MW = 384) by the reaction of $\mathbf{1 3}$ and $\mathrm{PhSH}(1: 1$ molar ratio) in $\mathrm{MeOH}$

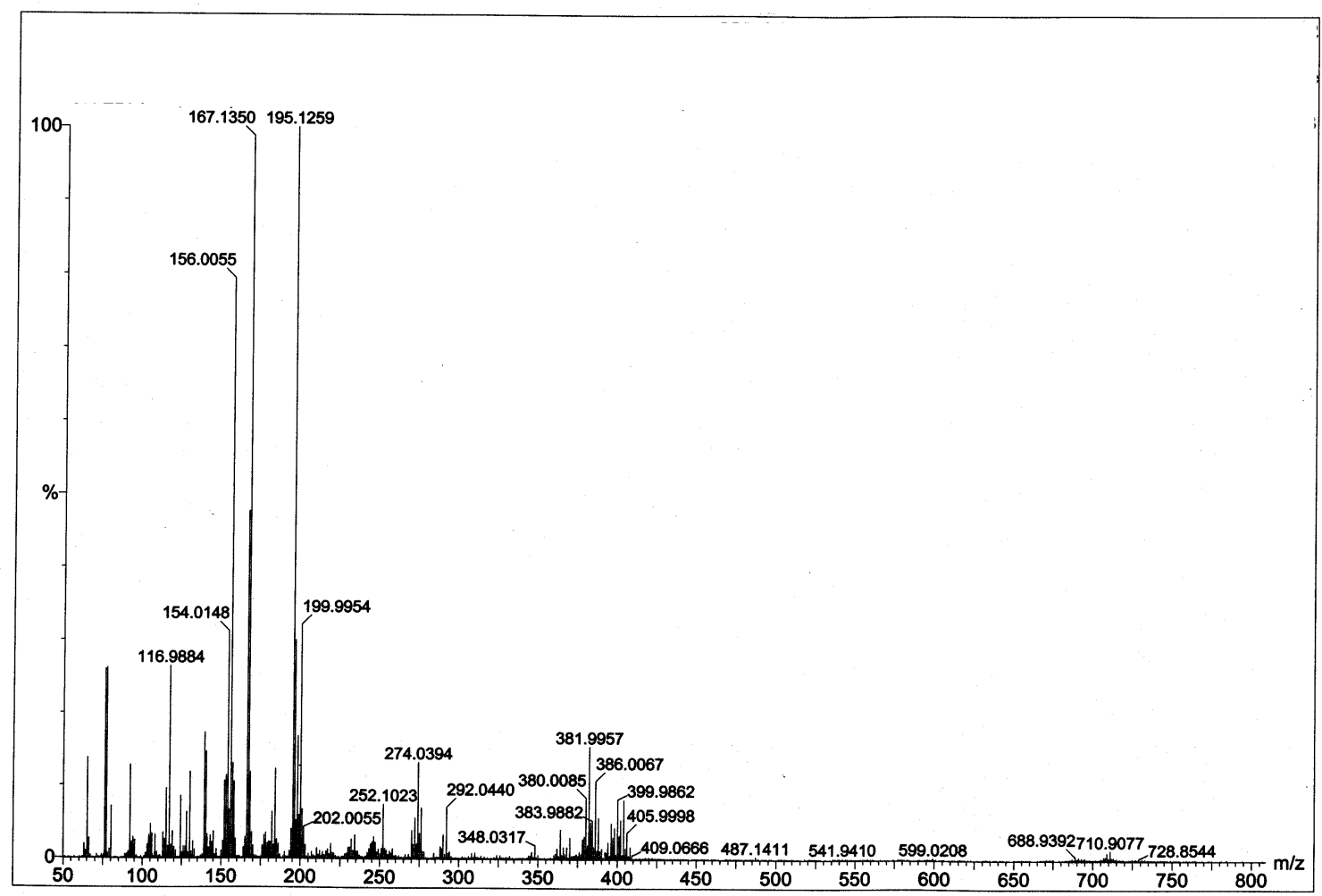

Molecular ion peaks at 400 and 382 are due to thioselenenate (65) and selenenylsulfide (67) respectively. 
Figure S-28. ES-MS of in situ generated 65 and 67 in $\mathrm{MeOH}$ and expansion from Figure S-61.

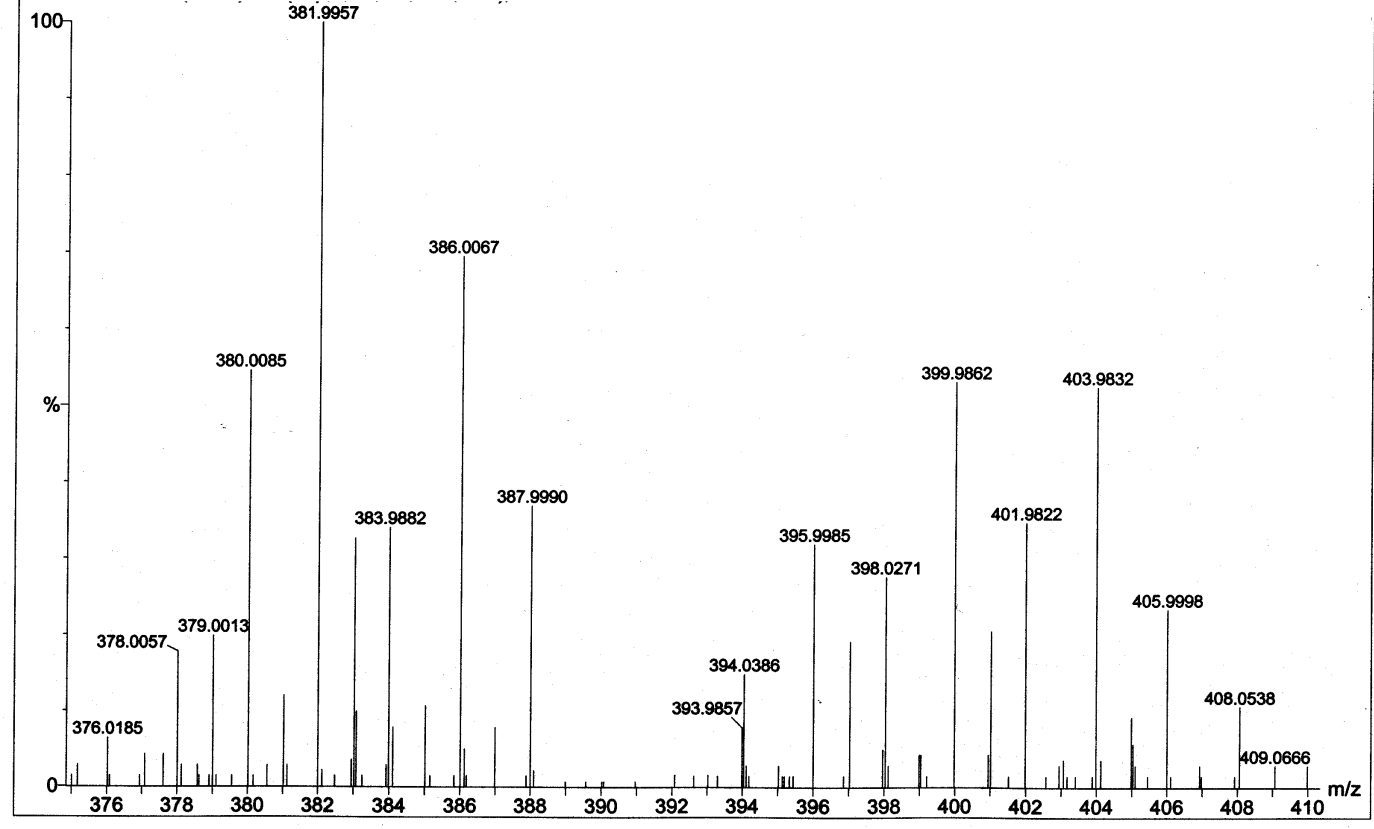


Figure S-29. ES-MS of in situ generated selenoxide $\mathbf{4 8}$ in $\mathrm{MeOH}$

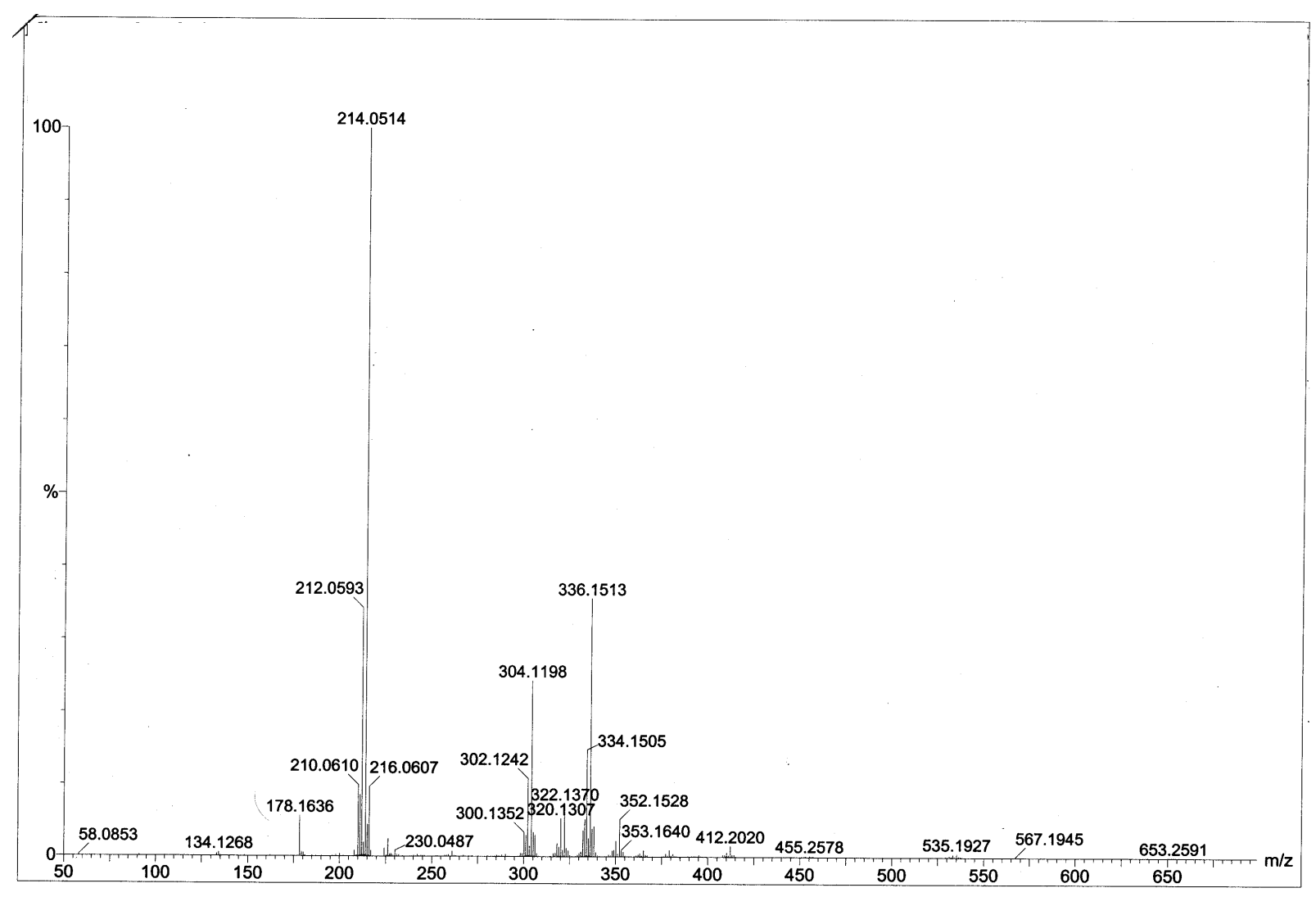

Molecular ion peak at 322, 336 and 352 are due to $\mathrm{RSe}(\mathrm{O}) \mathrm{CH}_{2} \mathrm{Ph}(\mathbf{4 8}) \mathrm{RSe}(\mathrm{OH})_{2} \mathrm{CH}_{2} \mathrm{Ph}$ (68) and $\mathrm{RSe}(\mathrm{OH})(\mathrm{OMe}) \mathrm{CH}_{2} \mathrm{Ph}(69)$ respectively. 
Figure S-30. ES-MS of in situ generated selenoxide (48) in $\mathrm{MeOH}$ and expansion from Figure S-63.

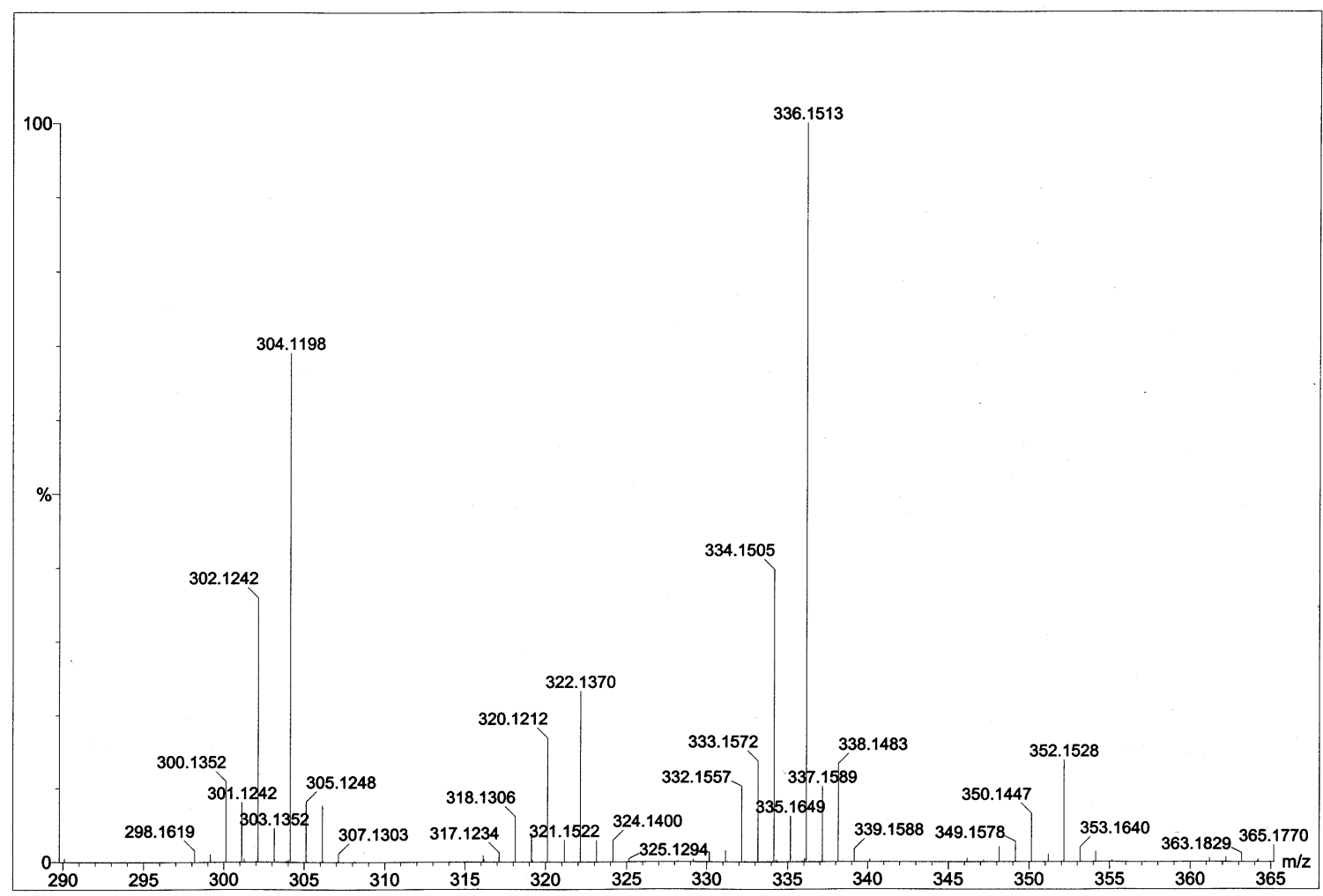

Molecular ion peaks at 322,336 and 352 are due to $\mathrm{RSe}(\mathrm{O}) \mathrm{CH}_{2} \mathrm{Ph}(\mathbf{4 8}) \mathrm{RSe}(\mathrm{OH})_{2} \mathrm{CH}_{2} \mathrm{Ph}$ (68) and $\mathrm{RSe}(\mathrm{OH})(\mathrm{OMe}) \mathrm{CH}_{2} \mathrm{Ph}(69)$ respectively. 
Figure S-31. ES-MS of in situ generated selenoxide [ $\mathrm{RSe}(\mathrm{O}) \mathrm{CH}_{2} \mathrm{Ph}(\mathbf{4 8})$ cal. $\mathrm{MW}=321$ ] in $\mathrm{MeOH}$ and expansion from Figure S-63

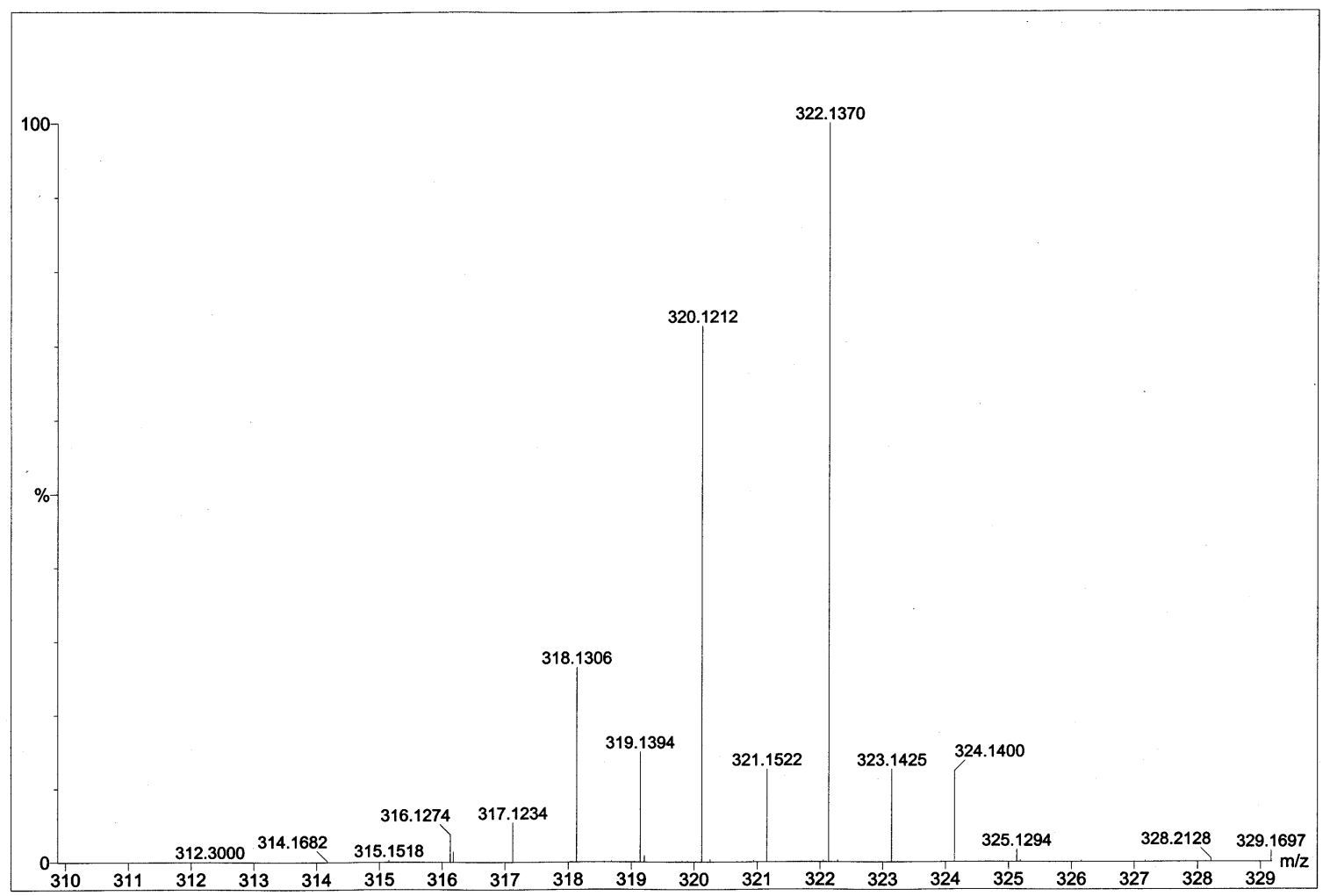


Figure S-32. ES-MS of in situ generated $\left[\mathrm{RSe}(\mathrm{OH})(\mathrm{OMe}) \mathrm{CH}_{2} \mathrm{Ph}(69)\right.$ cal. $\left.\mathrm{MW}=352\right]$ in $\mathrm{MeOH}$ and expansion from Figure S-63

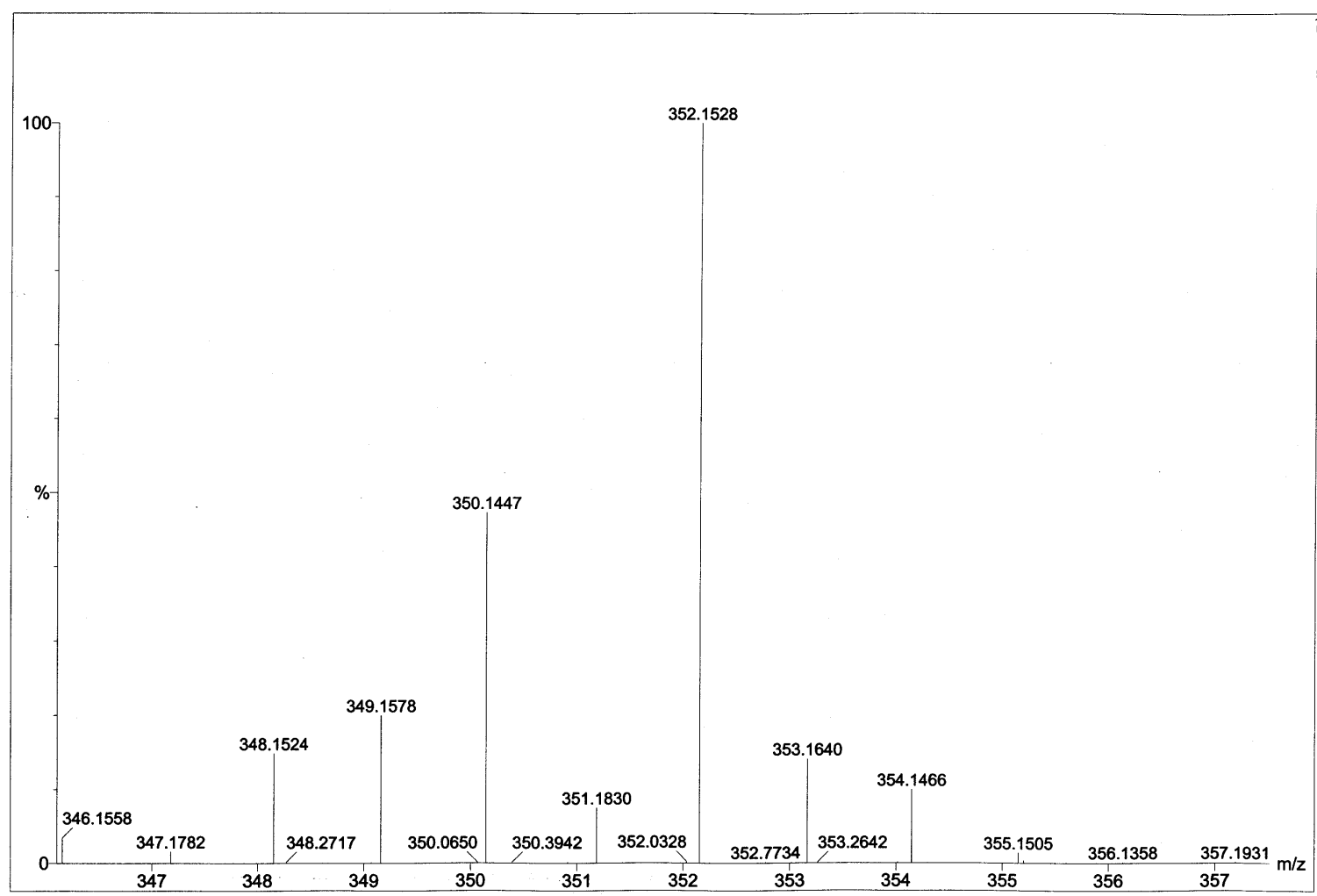


Figure S-33. ES-MS of in situ generated [ $\mathrm{RSe}(\mathrm{OMe})_{2} \mathrm{CH}_{2} \mathrm{Ph}(\mathbf{7 0})$ cal. $\mathrm{MW}=366$ ] in $\mathrm{MeOH}$ and expansion from Figure S-63

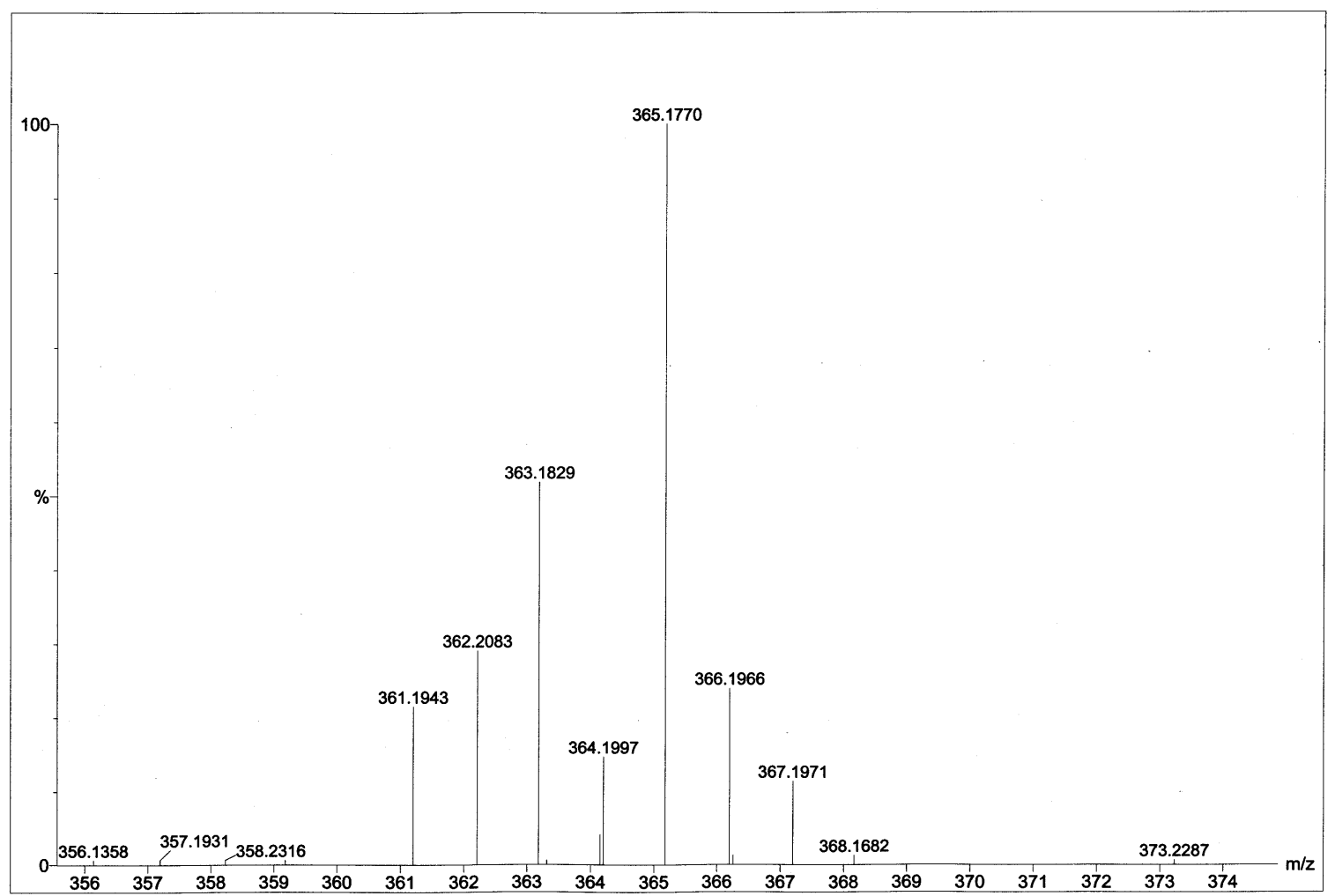


Figure S-34. ES-MS of reaction mixture of $\mathbf{4 8}$ and $\mathrm{PhSH}$ (1:1 molar ratio) in $\mathrm{MeOH}$

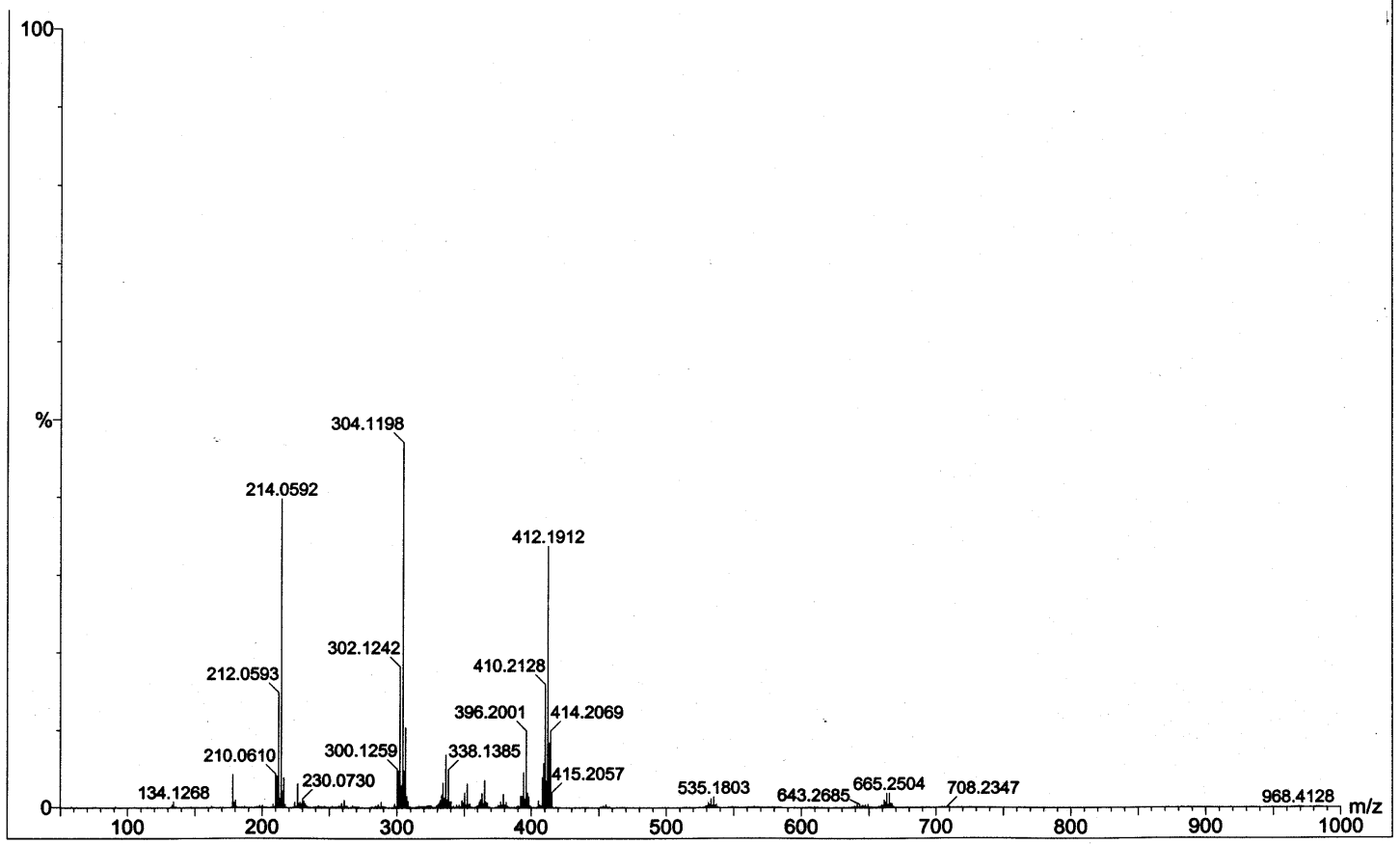

Molecular ion peak at 412 is due to $\mathrm{RSe}(\mathrm{SPh}) \mathrm{CH}_{2} \mathrm{Ph}$ (72). 
Figure S-35. ES-MS of in situ generated $\mathrm{RSe}(\mathrm{SPh}) \mathrm{CH}_{2} \mathrm{Ph}, 72$ calc $\mathrm{MW}=412$ from the reaction of selenoxide (48) and $\mathrm{PhSH}$ in $\mathrm{MeOH}$ and expansion from Figure $\mathrm{S}-68$

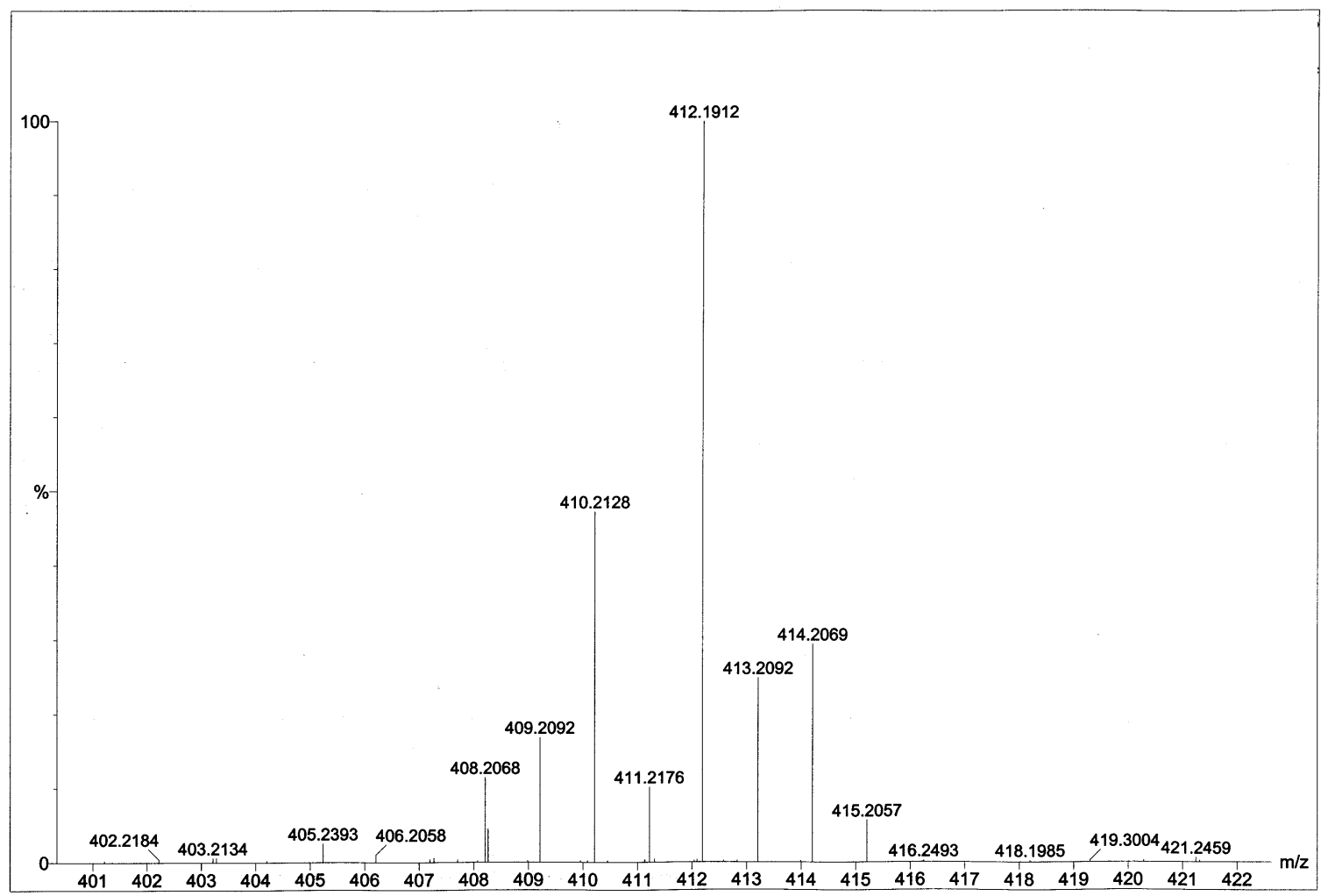


Figure S-36. ES-MS of in situ generated $\mathrm{RSe}(\mathrm{O}) \mathrm{Ph}, 54$ calc $\mathrm{MW}=484$.

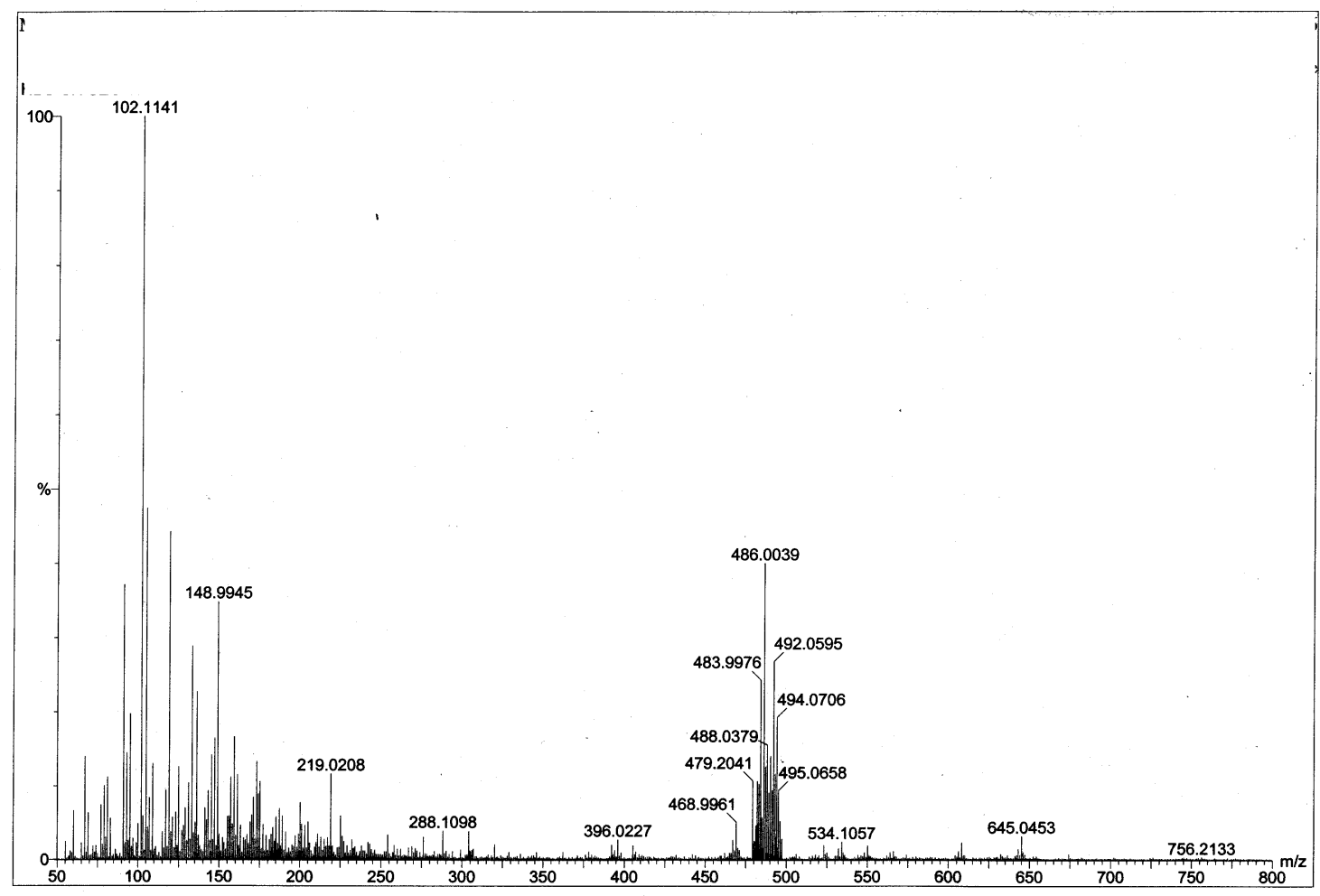


Figure S-37. ES-MS of in situ generated $\mathrm{RSe}(\mathrm{O}) \mathrm{Ph}, \mathbf{5 4}$ calc $\mathrm{MW}=484$ and expansion from Figure S-70

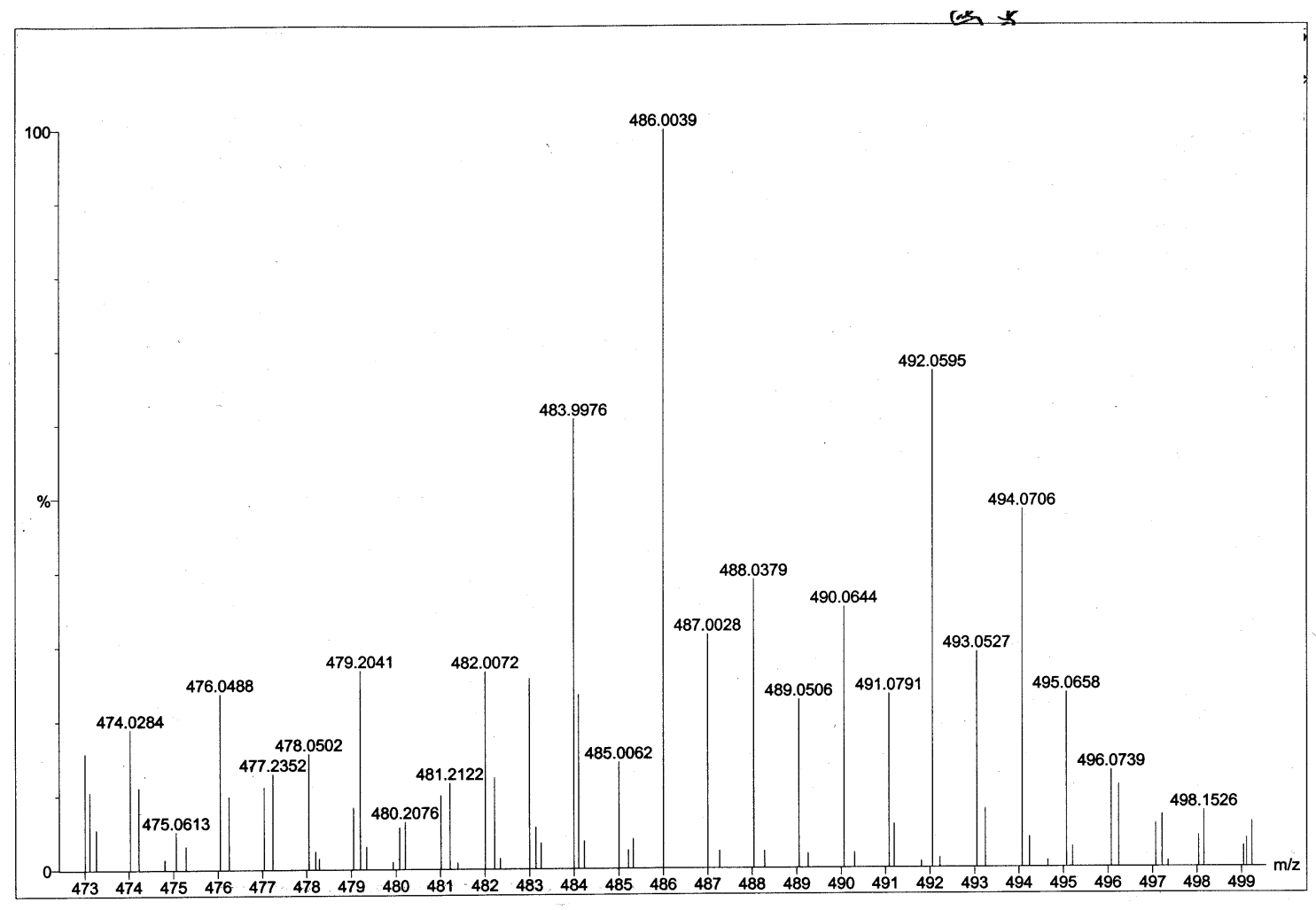


Figure S-38. Molecular structure of 27

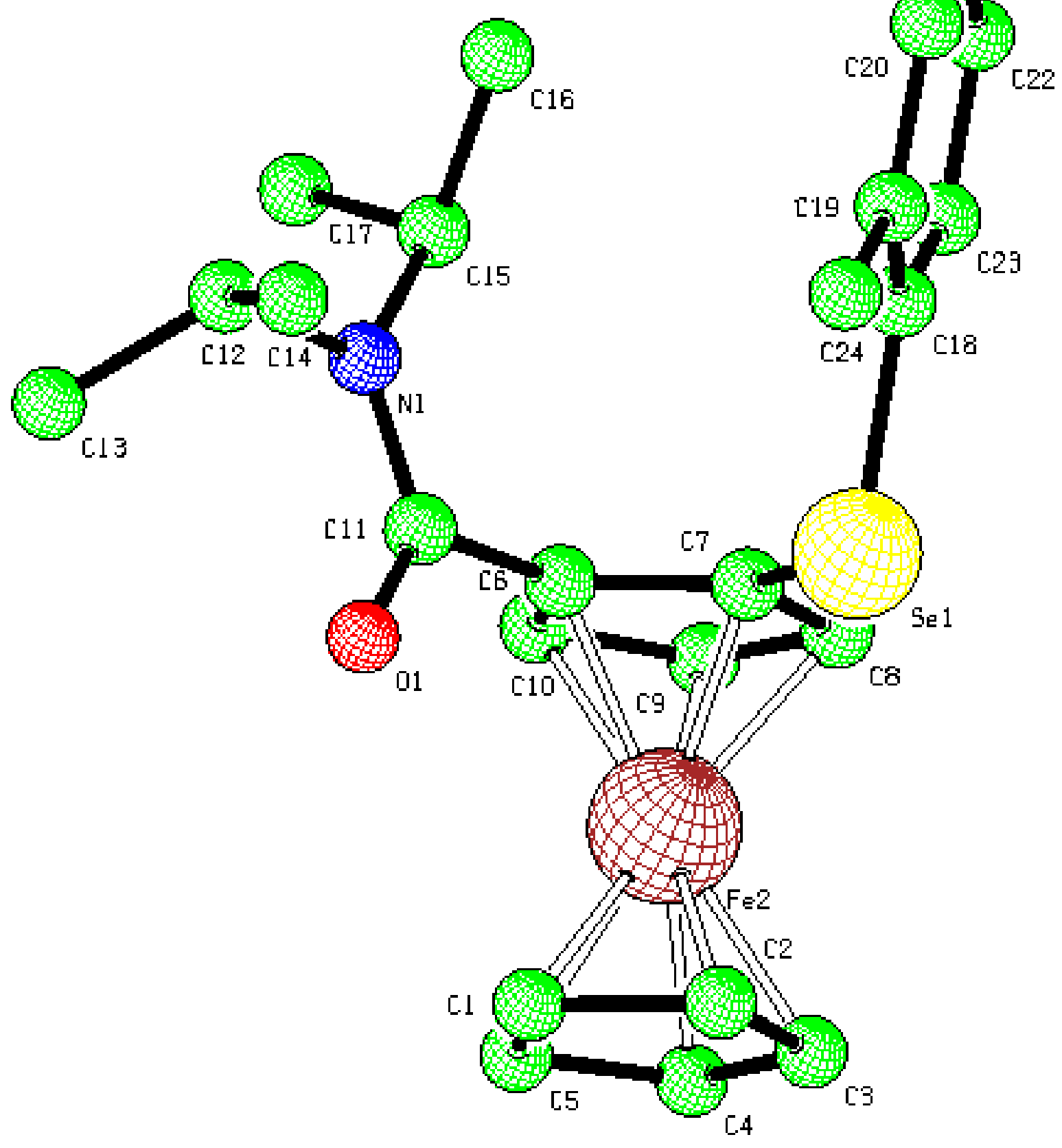


Figure S-39 Molecular structure of $\mathbf{3 4}$

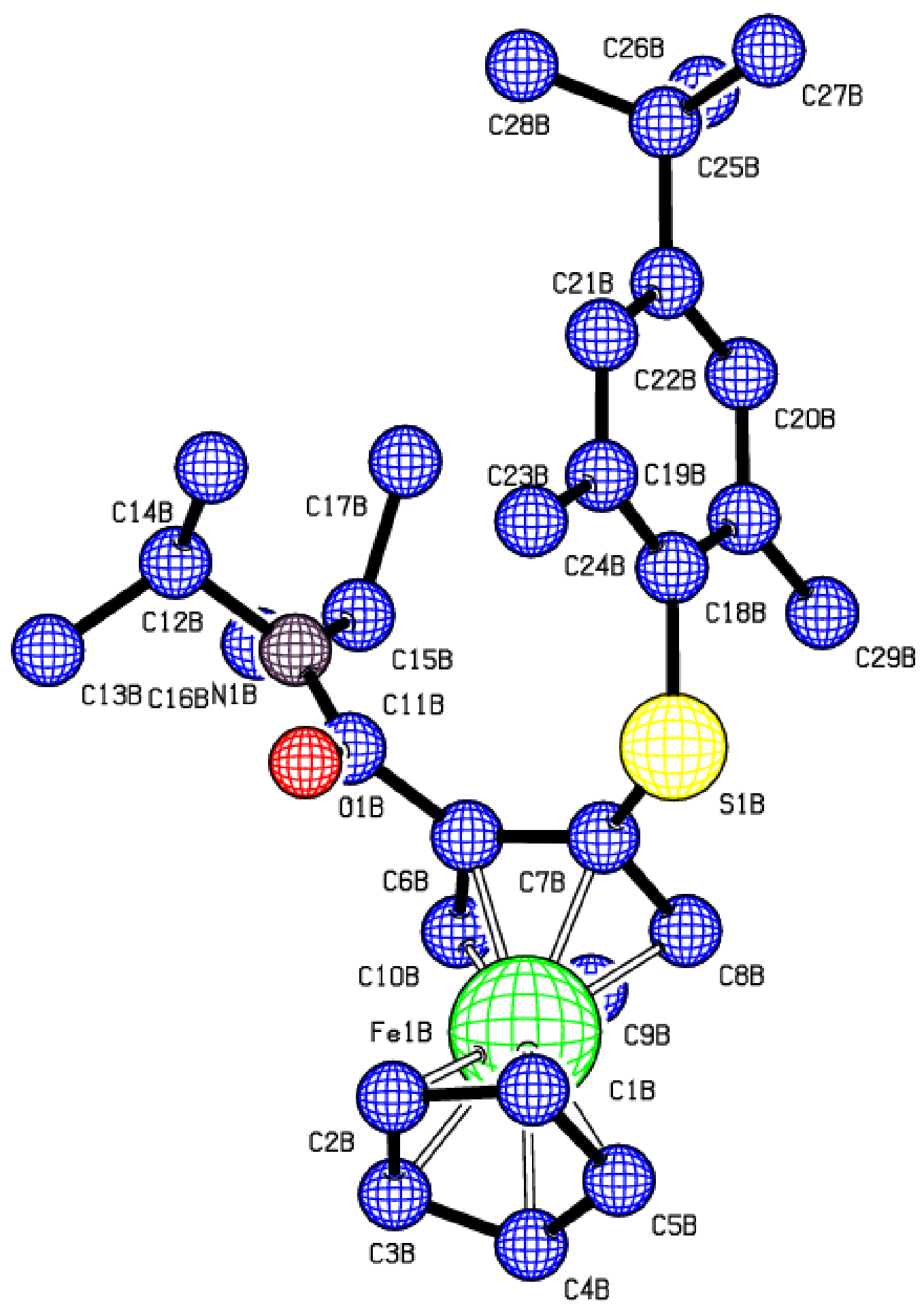




\section{References}

1. Oberhoff, M.; Duda, L.; Karl, J.; Mohr, R.; Erker, G.; Frohlich, R.; Grehl, M. Organometallics; $\mathbf{1 9 9 6 ; ~ 1 5 , ~} 4005$.

2. Roussyn, I.; Briviba, K.; Masumoto, H.; Sies, H. Arch. Biochem. Biophys. 1996, $330,216$.

3. Silva, V. D.; Woznichak, M. M.; Burns, K. L.; Grant, K. B.; May, S. W. J. Am. Chem. Soc. 2004, 126, 2409. 